\title{
Dispersion, Accumulation, and the Ultimate Fate of Microplastics in Deep-Marine Environments: A Review and Future Directions
}

\author{
Ian A. Kane ${ }^{1 *}$ and Michael A. Clare ${ }^{2}$ \\ 'School of Earth and Environmental Sciences, University of Manchester, Manchester, United Kingdom, ${ }^{2}$ National \\ Oceanography Centre, University of Southampton, Southampton, United Kingdom
}

\section{OPEN ACCESS}

Edited by:

David Mark Hodgson, University of Leeds, United Kingdom

Reviewed by:

Rachel E. Brackenridge, Heriot-Watt University,

United Kingdom

Aggeliki Georgiopoulou,

University of Brighton, United Kingdom

*Correspondence: Ian A. Kane

ian.kane@manchester.ac.uk

Specialty section: This article was submitted to Sedimentology, Stratigraphy and Diagenesis,

a section of the journal

Frontiers in Earth Science

Received: 02 March 2019

Accepted: 03 April 2019

Published: 30 April 2019

Citation:

Kane IA and Clare MA (2019)

Dispersion, Accumulation,

and the Ultimate Fate of Microplastics

in Deep-Marine Environments:

A Review and Future Directions.

Front. Earth Sci. 7:80

doi: 10.3389/feart.2019.00080
An estimated 8.3 billion tons of non-biodegradable plastic has been produced over the last 65 years. Much of this is not recycled and is disposed into the natural environment, has a long environmental residence time and accumulates in sedimentary systems worldwide, posing a threat to important ecosystems and potentially human health. We synthesize existing knowledge of seafloor microplastic distribution, and integrate this with process-based sedimentological models of particle transport, to provide new insights, and critically, to identify future research challenges. Compilation of published data shows that microplastics pervade the global seafloor, from abyssal plains to submarine canyons and deep-sea trenches (where they are most concentrated). However, few studies relate microplastic accumulation to sediment transport and deposition. Microplastics may enter directly into the sea as marine litter from shipping and fishing, or indirectly via fluvial and aeolian systems from terrestrial environments. The nature of the entry-point is critical to how terrestrially sourced microplastics are transferred to offshore sedimentary systems. We present models for physiographic shelf connection types related to the tectono-sedimentary regime of the margin. Beyond the shelf, the principal agents for microplastic transport are: (i) gravity-driven transport in sediment-laden flows; (ii) settling, or conveyance through biological processes, of material that was formerly floating on the surface or suspended in the water column; (iii) transport by thermohaline currents, either during settling or by reworking of deposited microplastics. We compare microplastic settling velocities to natural sediments to understand how appropriate existing sediment transport models are for explaining microplastic dispersal. Based on this analysis, and the relatively well-known behavior of deep-marine flow types, we explore the expected distribution of microplastic particles, both in individual sedimentary event deposits and within deep-marine depositional systems. Residence time within certain deposit types and depositional environments is anticipated to be variable, which has implications for the likelihood of ingestion and incorporation into the food chain, further transport, or deeper burial. We conclude that the integration of process-based sedimentological and stratigraphic knowledge with insights from modern sedimentary systems, and biological activity within them, will provide essential constraints on the transfer of microplastics to deep-marine 
environments, their distribution and ultimate fate, and the implications that these have for benthic ecosystems. The dispersal of anthropogenic across the sedimentary systems that cover Earth's surface has important societal and economic implications. Sedimentologists have a key, but as-yet underplayed, role in addressing, and mitigating this globally significant issue.

Keywords: microplastic, microfiber, deep-marine, turbidite, sedimentology, contourite, submarine canyon, Anthropocene

\section{INTRODUCTION: WHAT ARE MICROPLASTICS AND WHY DO WE CARE?}

Plastic is an incredibly versatile and inexpensive material, which is ubiquitous in modern life. Since mass-produced plastics appeared in the 1950s, production has increased exponentially (Andrady and Neal, 2009; Andrady, 2011). It has been estimated that 8.3 billion tons of plastic has been produced over the last 65 years; 6.3 billion tons of which is now predicted to be waste (Geyer et al., 2017). In 2012 alone, it is estimated that 288 million tons of plastic was manufactured (Plastics Europe, 2013). Between 4.8 and 12.7 million tons of plastic entered the Earth's oceans in 2010, with this figure estimated to rise by one order of magnitude by 2025 (Jambeck et al., 2015; Geyer et al., 2017). At least 5.25 trillion pieces of plastic are estimated to be afloat in the world's oceans (Eriksen et al., 2014).

Microplastics are small plastic particles and fibers, which are found in the present and recent anthropogenically modified environment (Figure 1). Microplastics have been defined as ranging from $<5 \mathrm{~mm}$ to $250 \mu \mathrm{m}$ in diameter (Arthur et al., 2009; and many others), however, here we follow Browne et al. (2011) and Claessens et al. (2011), and other subsequent prominent investigations of microplastics (e.g., Van Cauwenberghe et al., 2013, 2015; Vianello et al., 2013; Dekiff et al., 2014) who suggested that $<1 \mathrm{~mm}$ is more logical as this size class predominates in marine environments, and 'micro' generally refers to micrometer size range. Microfibers typically have lengths of $50 \mu \mathrm{m}$ up to a few $\mathrm{mm}$, and a diameter of $<10 \mu \mathrm{m}$. Primary microplastic particles are either manufactured (e.g., microbeads in cosmetics, blasting media, and other industrial applications; Zitko and Hanlon, 1991; United States Environmental Protection Agency [USEPA], 1992; Fendall and Sewell, 2009; Mason et al., 2016), or secondary, when derived from the breakdown of larger plastic debris (e.g., Andrady, 2011; Cole et al., 2011; ter Halle et al., 2016). Microfibers are derived from synthetic textiles and are typically discharged from sewage plants (e.g., Browne et al., 2011; Dubaish and Liebezeit, 2013). As an illustration of the numbers of microfibers released, Browne et al. (2011) showed that up to 1,900 microplastic fibers can be shed from a single garment during one wash cycle.

Despite being documented since the 1970s (e.g., Buchanan, 1971; Carpenter and Smith, 1972; Colton et al., 1974; Gregory, 1978), plastic waste in the marine environment did not attract significant scientific or societal attention until later, when it became clear that plastic waste was having a deleterious effect on marine wildlife, particularly larger fauna such as dolphins and turtles (Barnes et al., 2009; Gall and Thompson, 2015). Microplastics were documented as early as 1972 on the surface of the Sargasso Sea (Carpenter et al., 1972); however, concern for the potential consequences for ocean life has only recently been raised. These small and light plastic particles are readily available to many organisms throughout the marine foodweb. Furthermore, microplastics are preferential sites for the adhesion of organic pollutants, while their degradation can release toxic compounds (Teuten et al., 2009; Cole et al., 2011). Ongoing research is therefore required to quantify the risks posed to marine life (including fishing stocks), and potential knock on effects to human health (Van Cauwenberghe and Janssen, 2014; Galloway, 2015; Sharma and Chatterjee, 2017; Barboza et al., 2018).

Given their high mobility and long residence times, microplastics are found globally; from the beaches of isolated oceanic islands (Costa and Barletta, 2015; Lusher, 2015), within Antarctic currents (Lusher, 2015), to the seafloor of the Arctic (Bergmann and Klages, 2012; Bergmann et al., 2017; Kanhai et al., 2019) and the sea ice above it (Bergmann et al., 2017). In short, there appears to be no environment on Earth that has escaped microplastic pollution (Taylor et al., 2016). However, our knowledge of the locations of microplastic accumulation in the marine realm is presently incomplete, and in particular the distribution on the seafloor is poorly constrained (Thompson et al., 2004; Barnes et al., 2009; Ballent et al., 2013; Woodall et al., 2014; Martin et al., 2017). This is significant as it is estimated that approximately half of all plastics have a density greater than seawater (United States Environmental Protection Agency [USEPA], 1992; Morét-Ferguson et al., 2010). The seafloor is therefore considered a sink for global plastics, which could account for much of the 'missing' microplastic in global budgets (Goldberg, 1997; Thompson et al., 2004; Ballent et al., 2013; Van Cauwenberghe et al., 2013; Pham et al., 2014; Woodall et al., 2014; Fischer et al., 2015; Courtene-Jones et al., 2017; Hardesty et al., 2017; Underwood et al., 2017).

\section{Challenges}

Goldberg (1997) suggested that to better understand plastic accumulation on the seafloor required standardized monitoring to assess whether or not seafloor plastic contamination is increasing and whether or not it is affecting marine ecology. However, whilst seafloor microplastics have since been documented in an increasing number of studies, this has been done on a largely ad hoc basis, using existing cores and samples 

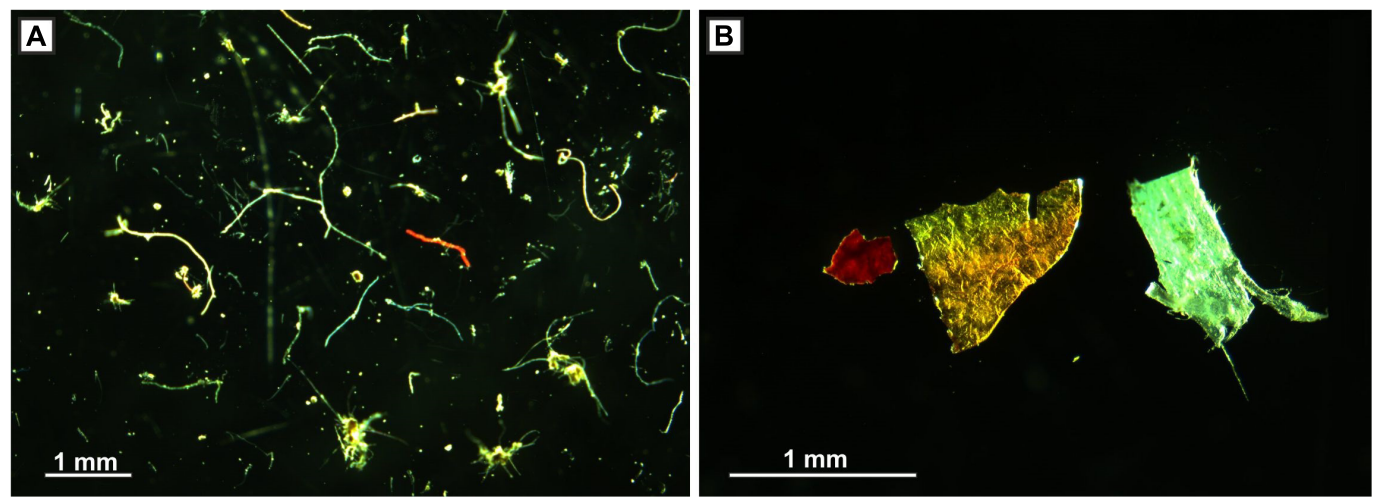

FIGURE 1 | (A) Microplastic fibers and (B) microplastic fragments; both from seafloor cores, c. 800 m water depth, Tyrrhenian Sea.

from older studies. Attention has been paid to ingestion of microplastics by seafloor organisms, however, there has been extremely limited attention paid to the physical mechanisms that control how microplastics reach the seafloor, how they are distributed and what governs their ultimate fate (e.g., Gregory, 2009; Corcoran et al., 2017; Graca et al., 2017; Horton and Dixon, 2017). Process-based sedimentological studies routinely relate sediment and other particulate accumulations to the processes that transport, deposit, and bury them. The present lack of characterization and quantification of the processes that control the influx, distribution, and ultimate burial of microplastics in the oceans, provides an opportunity for the application of process-based sedimentology to assess this globally significant issue (Hodgson et al., 2018a).

\section{Aims}

Here, we aim to synthesize existing knowledge on seafloor microplastic distribution, and integrate that with a processbased understanding of how particles are transported, and the known sedimentology of deep-marine systems. We do this in order to provide new insights from recent research and to identify future research challenges. We specifically address the following questions:

(1) What types of microplastics are found on the seafloor and where do they come from (see section "Where Do Microplastics Come From and What Types Are Found on the Seafloor?")?

(2) How are onshore microplastic transport pathways linked to offshore pathways? (see section "How Might Terrestrial Microplastics Be Introduced to DeepSea Environments?") This is currently a missing part of the microplastic cycle (Zalasiewicz et al., 2016). More specifically, are those pathways direct, or more complex with staggered transport and filtering mechanisms? Because of the dominance of river emissions in contributing microplastics to the world's oceans (Lebreton et al., 2017), here, we focus primarily on clastic systems, but many of our discussions will also relate to carbonate systems.
(3) Based on existing knowledge, where do microplastics accumulate on the seafloor, and is there disproportionality in where they are found (see section "In Which Physiographic Domains Have Microplastics Been Documented to Accumulate at Seafloor?")? How important for example are different physiographic domains such as submarine canyons, which are known conduits for sediment and organic carbon transport and nutrients, compared to, open continental slopes?

(4) Based on what we know of microplastic density, size and shape, what physical processes might be responsible for their transport and deposition on the seafloor (see sections "Settling Velocities of Microplastic Particles," "Enhanced Suspension Fall-Out Due to Reversing Buoyancy and Biological Modifications," "Inhibited Settling due to Thermohaline Stratification and Influence of Near-Bed Ocean Currents," and "Modified Settling in Sediment-Laden Fluids and the Importance of Sediment Gravity Flows")? What are the unique aspects of microplastics transport compared to natural sediments? Do microplastics accumulate within certain grain size ranges as a product of the environment in which they are found?

(5) Where should we expect microplastics to be deposited within individual deep-sea environments (see section "Where Should We Expect Microplastics to Be Deposited Within Individual Deep-Sea Deposits?"), i.e., do they have an affinity for different sedimentary facies, and how might they vary across and down systems such as submarine channels, levees and lobes? What are the implications of these predicted vertical and lateral distributions for deep-sea ecosystems?

(6) What is likely to be the ultimate fate of microplastics (see section "Implications for the Long-Term Distribution of Microplastics Within Depositional Settings and Their Ultimate Fate")? We explore the implications of deep-sea sediment transport that may initially result in preservation of microplasticbearing deposits over short timescales, but over longer 
time-scales may be subject to repeated re-exhumation and remobilization (e.g., canyon filling and flushing). We address this by comparing recent repeat seafloor surveys that span periods of days to decades in active settings, to consider the local residence time and ultimate fate of microplastics within the depositional record over anthropogenic timescales.

\section{Objectives and Datasets}

In order to address the questions outlined above, we synthesize the following datasets:

(1) Observations of microplastic distributions from various published studies.

(2) Process-based observations and models developed for distribution of lightweight, highly mobile particles in deep-sea systems such as organic carbon and pollutants.

(3) Experimental analysis of settling rates and settling behavior of microplastics.

(4) Measurements of sediment transport processes using recent direct monitoring technology (e.g., of river plumes, turbidity currents, internal tides).

(5) High resolution repeat seafloor surveys to understand the dynamic nature of active deep-sea sediment transport systems.

(6) Geological archives that demonstrate what is ultimately preserved in the depositional record, including sediment cores from modern systems and ancient outcrops that form the basis for the development of system-wide ecological models.

\section{WHERE DO MICROPLASTICS COME FROM AND WHAT TYPES ARE FOUND ON THE SEAFLOOR?}

The global production of plastic increased from approximately 30 million tons in the 1960 s, to $>140$ million tons by the turn of the 21st Century (Goldberg, 1997; Thompson et al., 2004). It has proven challenging, however, to quantify the input rate of plastics to the oceans as there are only poor constraints on degradation rates in different environments, and plastic age does not necessarily reflect the age it was deposited (Ryan et al., 2009). In addition, there is a multitude of pathways for plastics to reach the seafloor and these may be heavily modulated by the effects of both surface and water-column currents (e.g., thermohaline currents) (Ryan et al., 2009; Cole et al., 2011; Doyle et al., 2011). A general trend of increasing macroplastic pollution has been observed in long term monitoring studies (e.g., Chiba et al., 2018; Maes et al., 2018); however, an encouraging decline in the occurrence of plastic bags has been noted in the North Sea, suggesting that legislation can have a positive impact (Maes et al., 2018). Only in the last 5 years have microplastics been identified in the deep and abyssal oceans; the largest marine habitat on the planet (Woodall et al., 2014) (Figure 2). This new identification may in part be explained by advances in analytical approaches that enable microplastic identification, coupled with a growing societal concern to understand the global significance of plastic pollution; however, it is highly likely that the deep-sea is now experiencing the legacy of the exponential increase in microplastic production over the past five decades (Thompson et al., 2004).

Microplastics documented on the seafloor are dominated by fibers. The main source of microplastic particles is thought to be the breakdown of primary plastics (e.g., Andrady, 2011; Cole et al., 2011; ter Halle et al., 2016). These primary plastics are typically those which are not recycled and undergo breakdown in the terrestrial realm, e.g., on land and in rivers, and are transported to the marine realm either as microplastics or larger pieces which may degrade on the sea surface or seafloor (e.g., Willis et al., 2017; Hurley et al., 2018; Pierdomenico et al., 2019) (see section "Enhanced Suspension Fall-Out due to Reversing Buoyancy and Biological Modifications" on reversing buoyancy), as well those from fishing boats and shipping (Pham et al., 2014). Microfibers are derived from synthetic textiles and are typically derived from sewage plants where they are not retained, and from fishing gear (e.g., Browne et al., 2011; Dubaish and Liebezeit, 2013). The distribution and dynamic behavior of microplastics in the water column is poorly constrained but is known to be affected by dredging, trawling, tidal currents, and other processes which affect turbulence in the water column (e.g., Browne et al., 2010, 2011; Claessens et al., 2011; Van Cauwenberghe et al., 2015; Alomar et al., 2016; Moreira et al., 2016).

\section{HOW MIGHT TERRESTRIAL MICROPLASTICS BE INTRODUCED TO DEEP-SEA ENVIRONMENTS?}

Sediment, including macroplastic and microplastic, is transported to coastal zones by rivers, wind and ice. Rivers, in particular, are key agents in the transport of microplastics to the coast (e.g., Moore et al., 2011; Klein et al., 2015; Mani et al., 2015; Horton et al., 2017; Lebreton et al., 2017; Willis et al., 2017; Hurley et al., 2018; Pierdomenico et al., 2019). Other contributors of microplastics to the coastal zone include wastewater from treatment plants, shipyards, harbors, and other industries (e.g., Stolte et al., 2015), and urban run-off (e.g., Patters and Bratton, 2016) (Figure 3). When rivers reach the coast, the sediment within them is either sequestered into shallow marine sediment deposits, where it is prone to reworking by coastal processes including longshore drift, or it is fed into a submarine canyon head (e.g., Zalasiewicz et al., 2016; Blum et al., 2018; Pierdomenico et al., 2019) (Figure 4). Recent studies have shown that microplastics in beach sands can also be derived from oceanic waste transported by landward-directed surface currents and that this in some cases can dominate over delivery of river-derived microplastics (Chubarenko et al., 2018).

The duration of sediment storage in the onshore realm generally depends on the relief of the margin, which is related to the tectonic regime. Steep, tectonically active margins tend to have minimal onshore storage (e.g., Romans et al., 2016), and hence sediment and microplastics have a short residence time onshore; the opposite being true for mature, passive margins 


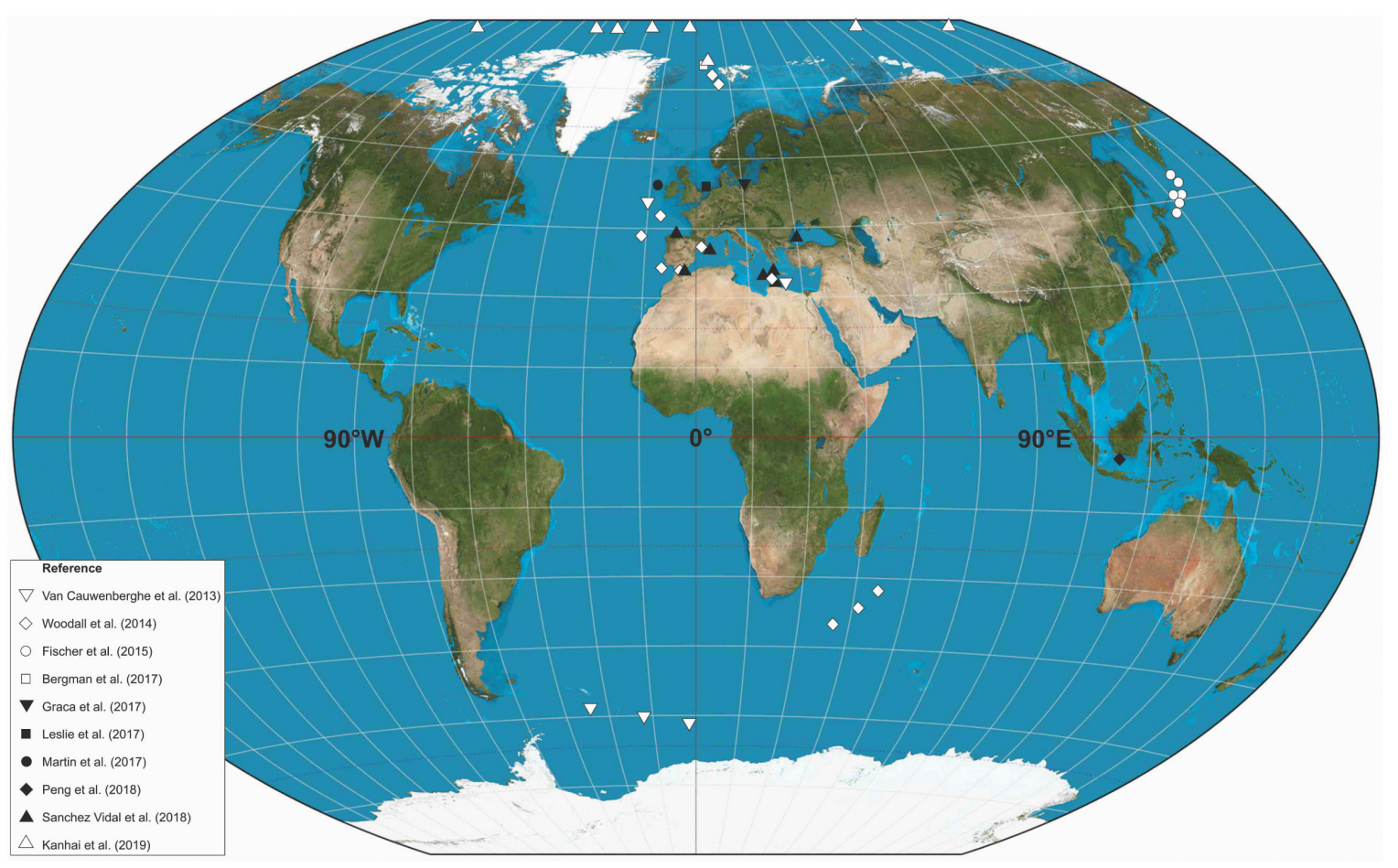

FIGURE 2 | Global distribution of studies which have identified microplastics in deep-marine sediment samples. Positions marked are approximate.

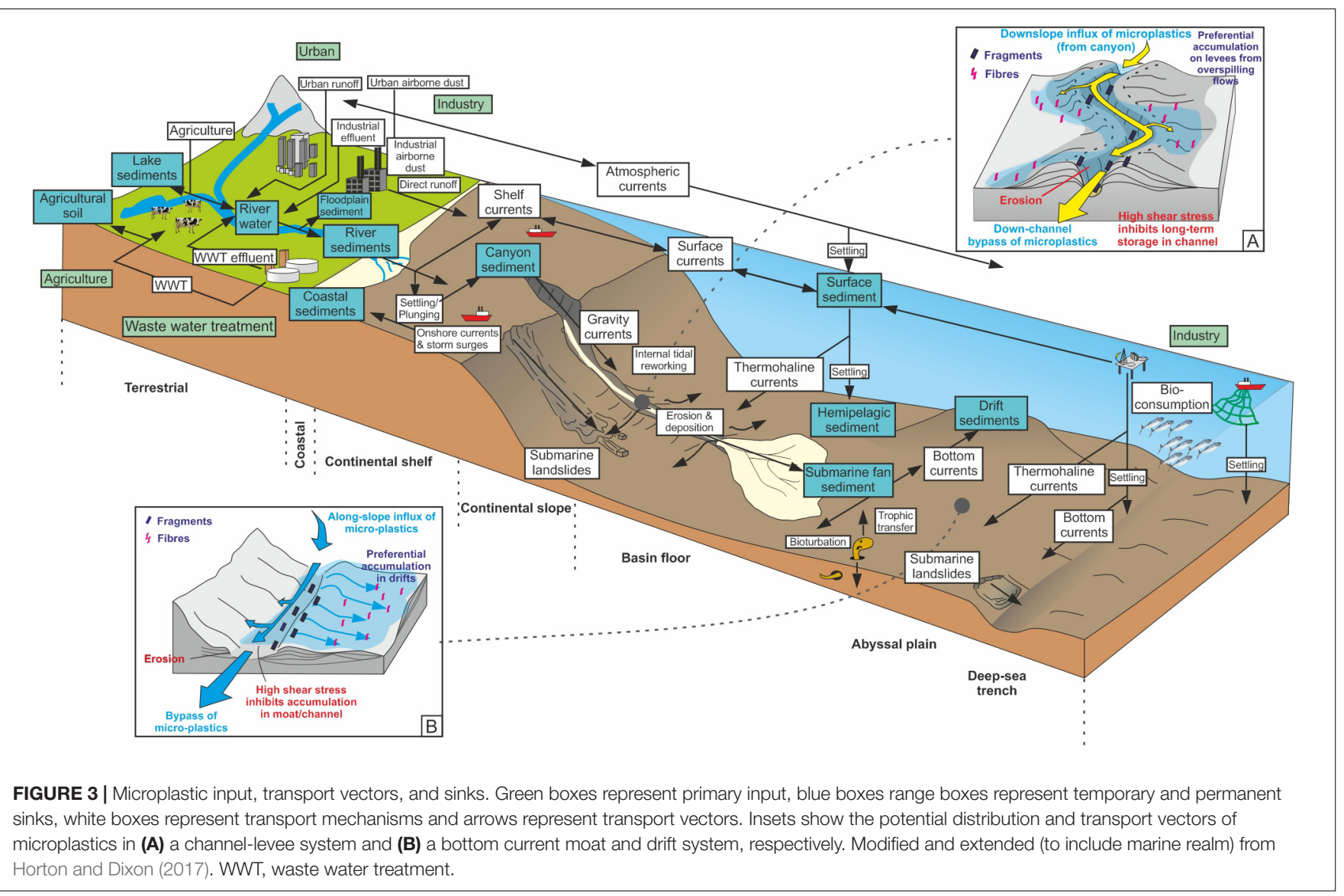




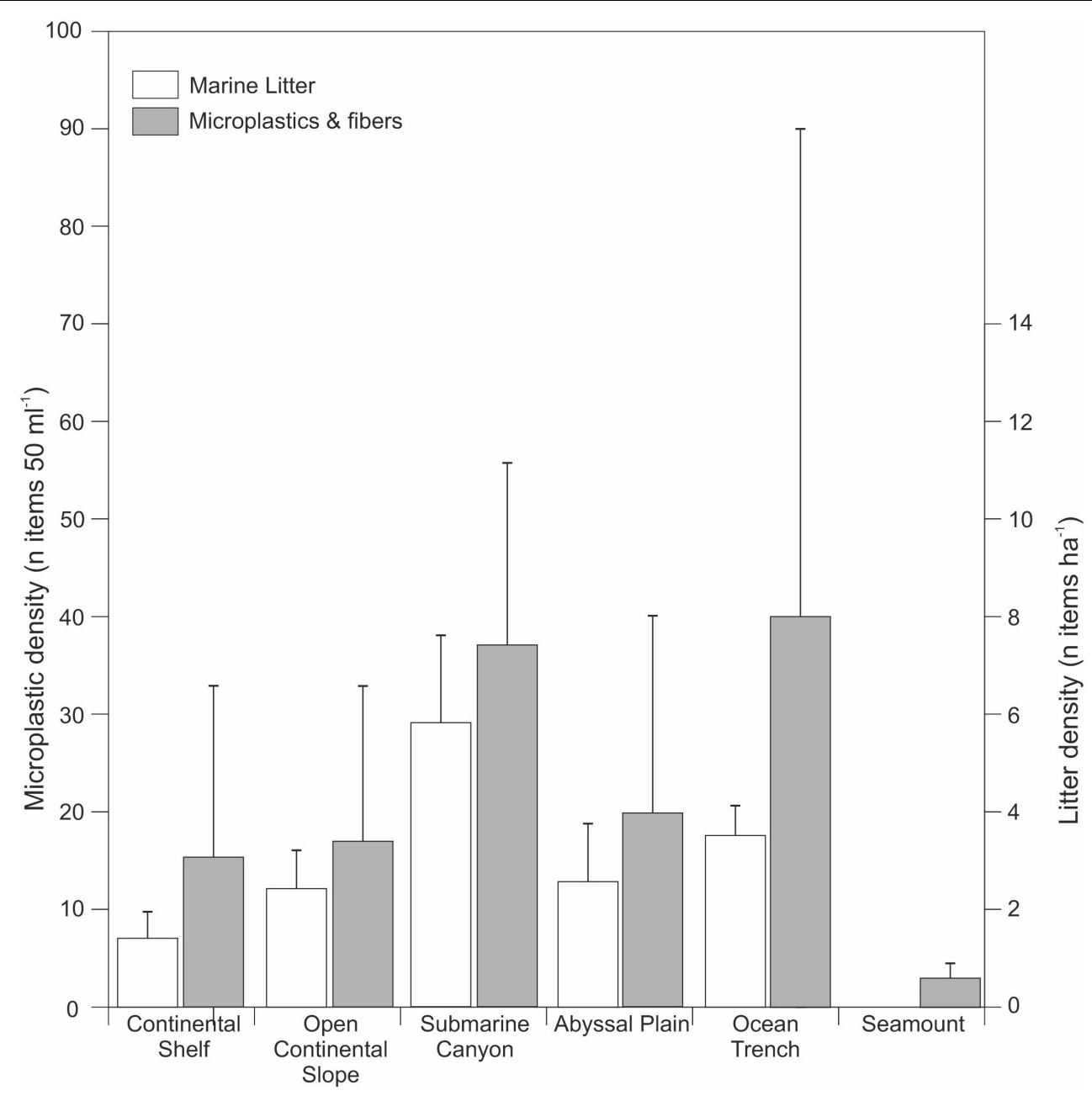

FIGURE 4 | Compilation of microplastic and microfiber distribution in deep-marine sediments and their gross depositional environments (data compiled from: Van Cauwenberghe et al., 2013; Woodall et al., 2014; Fischer et al., 2015; Bergmann et al., 2017; Graca et al., 2017; Leslie et al., 2017; Martin et al., 2017; Peng et al., 2018; Sanchez-Vidal et al., 2018; Kanhai et al., 2019). As a comparison data from marine litter distributions collected by Pham et al. (2014) are shown.

(e.g., the Mississippi River feeding into the Gulf of Mexico Galloway et al., 2013). Longer duration of onshore storage will allow more time for macroplastics to degrade and for larger fragments to break into smaller fragments (Figure 3). The downstream transfer of sediment and microplastics in many systems may be staggered, particularly on passive margins with extensive drainage systems. Plastics may undergo temporary storage during periods of relatively low discharge, but be reexhumed during flood events wherein they are flushed seawards (Hurley et al., 2018). The tectonic configuration of the continental margin also controls the transfer pathways of sediment and microplastics from rivers to deep-sea sediment routing systems, such as submarine canyons. As well as featuring steep and short onshore catchments, active margins are characterized by narrow continental shelves, and steep continental slopes, typically incised by submarine canyons (e.g., Cascadia and California margins, NW United States). Passive margins are characterized by long and relatively lower relief catchments with gentler slopes and wider shelves; hence there is often a much greater distance between rivers and the continental slope (with the exception of infrequent instances where submarine canyons cut back into the continental shelf; e.g., Congo Canyon, West Africa; Babonneau et al., 2002). The role of the continental shelf as both a filter and a conveyor of sediment is critical and especially so in today's highstand sea-level conditions where slope conduits may be isolated from a feeder system (e.g., Cosgrove et al., 2018). In such detached scenarios, areas of broad continental shelf may provide loci for long-term storage or along-contour redistribution of microplastics (as is also the case for organic carbon), depending on the vigor of along-shelf currents and other oceanographic perturbations, such as storm waves and surges (e.g., Aller and Blair, 2006).

We now consider a range of shelf and slope configurations that may explain variability in the efficiency of microplastics transfer from onshore to the deep-sea (Figure 4). At one end of the spectrum are situations where a river debouches directly into an offshore canyon head, in which the efficiency of 


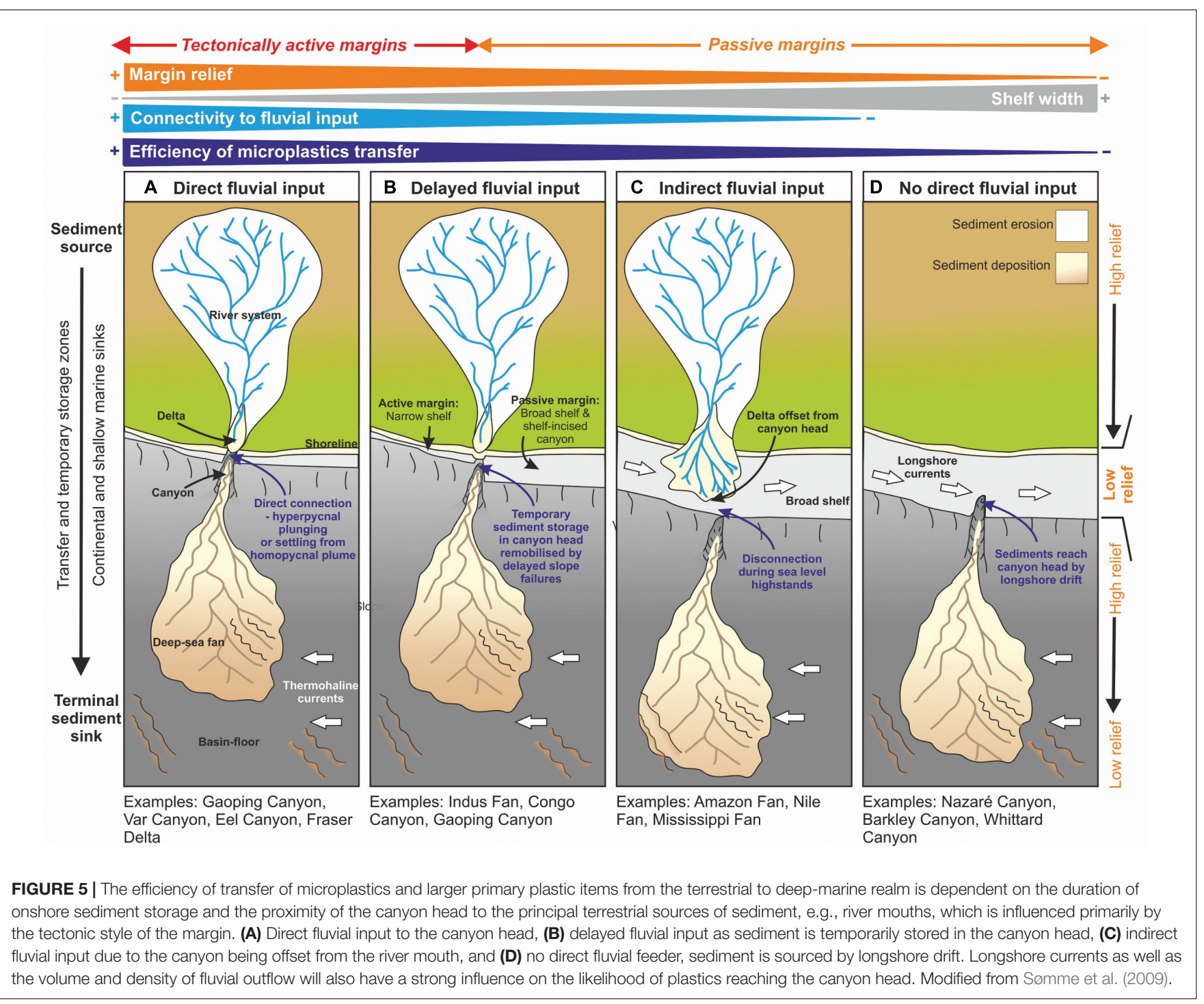

transfer for denser microplastics is likely to be high (Figure 5A). This is particularly the case where rivers with sufficiently high concentrations enter the sea, and lead to plunging of dense sediment-laden water (termed 'hyperpycnal flow') that initiates a turbidity current (e.g., Gaoping Canyon, Taiwan; Var Canyon, NW Mediterranean; Mulder et al., 2003; Khripounoff et al., 2009; Carter et al., 2012) (Figure 5). High outflows in such settings may also lead to rapid sediment accumulation in the canyon head, setting up slope failures, or settling from homopycnal river plumes, that can also trigger turbidity currents (Carter et al., 2012; Pope et al., 2017; Hizzett et al., 2018). The Messina Strait canyons of the Mediterranean are subject to flash-flood induced hyperpycnal flows, and these have been shown to transport huge volumes of anthropogenic waste to over 1,000 $\mathrm{m}$ water depth (Pierdomenico et al., 2019). These systems are termed 'reactive' with the source sediment supply conditions being relatively wellrecorded in the deposits of the sink (Figure 6); an example is the La Jolla canyon-channel system (Romans et al., 2016).
In such high efficiency transfer zones, the direct connection between terrestrial outflow and submarine canyon would be expected to result in a concentration of microplastics; in particular the larger size fractions but potentially also microfibers. If a river lacks a direct connection to a submarine canyon (Figures 5B-D), then along-shelf currents and wave action can redistribute and disperse sediments, thus reducing the efficiency of the river to slope connectivity (Mulder et al., 2012; Eidam et al., 2019). These systems may be termed 'buffered,' with the input conditions being less faithfully recorded in the sink (Figure 6); an example being the Indus River - Indus Submarine Fan (Romans et al., 2016). It has been demonstrated that longshore drift acts as a grain size segregator, with the finer and/or hydrodynamically lighter grains being more-readily transported along the shelf (Aller and Blair, 2006). Sediment will be transported along the shelf, until the load is diminished through wave and storm action, or until it meets an intersecting canyon head (e.g., La Jolla or Monterey Canyons, California; 


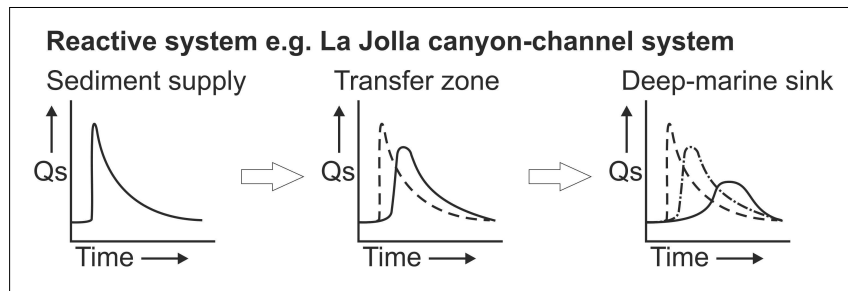

Buffered system e.g. Indus River - Submarine Fan

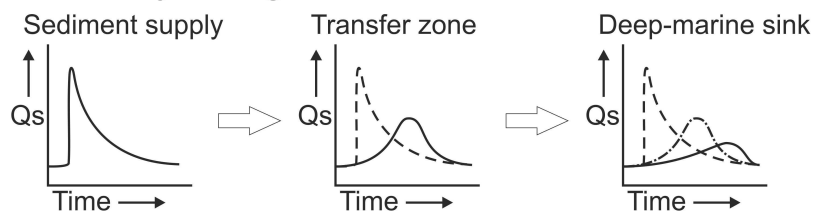

FIGURE 6 | Reactive versus buffered sediment delivery systems. Longer residence periods for sediment in the buffered systems suggests that plastics may be more degraded, both physically and chemically, suggesting that plastics delivered in these systems will be more degraded and smaller. In the buffered example, the seafloor expression of surges in plastic production may significantly lag behind their introduction to the sedimentary environment. Modified from Romans et al. (2016).

Xu et al., 2002; Covault et al., 2007) (Figures 5C,D). Thus, microfibers and the lightest microplastic particles will be morereadily dispersed in low-efficiency and buffered margin transfer zones (e.g., disconnection between river and canyon/continental slope, wide shelf dominated by currents), becoming preferentially transported along the coast and shelf. The general advection of fine grained particles over the shelf edge during longshore drift is anticipated to be widespread away from zones of fluvial input, both due to shelfal processes and hydrodynamic aspects, some of which are unique to microplastics. We now discuss some of the key properties of microplastics, and how they compare to sand and mud particles that are more routinely characterized and modeled in sediment transport studies.

\section{IN WHICH PHYSIOGRAPHIC DOMAINS HAVE MICROPLASTICS BEEN DOCUMENTED TO ACCUMULATE AT SEAFLOOR?}

Despite the relative infancy of marine microplastics research, a considerable, and steadily growing, number of publications now provide compelling evidence of the pervasive nature of microplastics across the seafloor worldwide. Many studies show that deep-sea microplastics occur in similar (or even higher) concentrations as in intertidal and shallow sub-tidal sediments, with microplastic particles being distributed primarily, but not solely, around input points such as submarine canyons (e.g., Woodall et al., 2014; Taylor et al., 2016; Bergmann et al., 2017; Hurley et al., 2018) (Figures 2, 3 and Table 1). Analysis of previous deep-sea studies that sampled seafloor sediments reveals that submarine canyons and ocean trenches are the physiographic domains with the highest density of microplastics
(Table 1 and Figure 4). These two environments feature almost double the microplastic density at seafloor compared to other deep-sea settings, such as continental shelves, open continental slopes, abyssal plains and seamounts (Figure 4). While a relatively wide range of settings have been sampled, it should be noted that there is some geographic bias to the existing sampling for microplastics (e.g., Atlantic, Mediterranean, and Pacific focus). Future efforts should ensure a wider geographic, as well as physiographic coverage.

Submarine canyons have previously been shown to be marine litter hotspots, especially where they occur in close proximity to industrial and densely populated coastal areas (Mordecai et al., 2011; Pham et al., 2014; Tubau et al., 2015; Buhl-Mortensen and Buhl-Mortensen, 2017). Sites offshore from popular tourism centers can be inundated with large quantities of litter that is transported offshore and to deeper water (over 1,000 m water depth) following storms or during seasonal cascades of dense water (Tubau et al., 2015; Pierdomenico et al., 2019). A study of the Lisbon, Blanes, Guilvinec, and Setubal canyons (NE Atlantic) found litter at all sites and all water depths (from 35 to 4,500 $\mathrm{m})$, with a higher density than from all other physiographic settings; reaching an average of $9.3 \pm 2.9$ items $^{-1}$ (Pham et al., 2014). Perhaps unsurprisingly, there is a close match between the recorded distribution of marine litter and microplastic fragments in the ocean (Figure 4).

Levels of microfiber contamination in bottom waters have been shown to be considerably higher than in surface waters, for example, 11 microfibers per liter of water were sampled in the Mariana trench, western Pacific Ocean, compared to a few pieces per liter in surface waters and 200-2,200 per liter of sediment (Peng et al., 2018). This may partially explain the relative abundance of microplastics in ocean trenches, with the presence of larger plastics and marine litter in that setting being attributed mostly to fishing and shipping activities (Peng et al., 2018).

While previous studies have provided valuable information on the type and abundance of microplastics in seafloor sediments, they have not yet included any detailed sedimentological data that can explain these physiographic biases for microplastic distribution, nor to enable prediction of how microplastics may be distributed within different system types (e.g., across the full extent of a deep-sea submarine channel system). As an example, the lack of microplastic particles identified at the deepsea Congo Fan was viewed as anomalous due to the presence of major industrial cities on the Congo River (Van Cauwenberghe et al., 2013), but no information is provided about whether the part of the fan sampled was active (i.e., subject to recent turbidity current activity or near-bed oceanographic currents), nor regarding the grain size of the host sediment. Previous studies have demonstrated that, while much of the Congo canyon, deep-sea channel and fan system is a highly active conduit for sediment and organic carbon transport in the present day (Khripounoff et al., 2003; Azpiroz-Zabala et al., 2017), not all of the deep sea distributary networks are active (Picot et al., 2019). Thus, without any detailed information on the seafloor sediments and specific location within the submarine channelfan system, it is challenging to determine how representative one core location is for an entire system. Recent studies in 


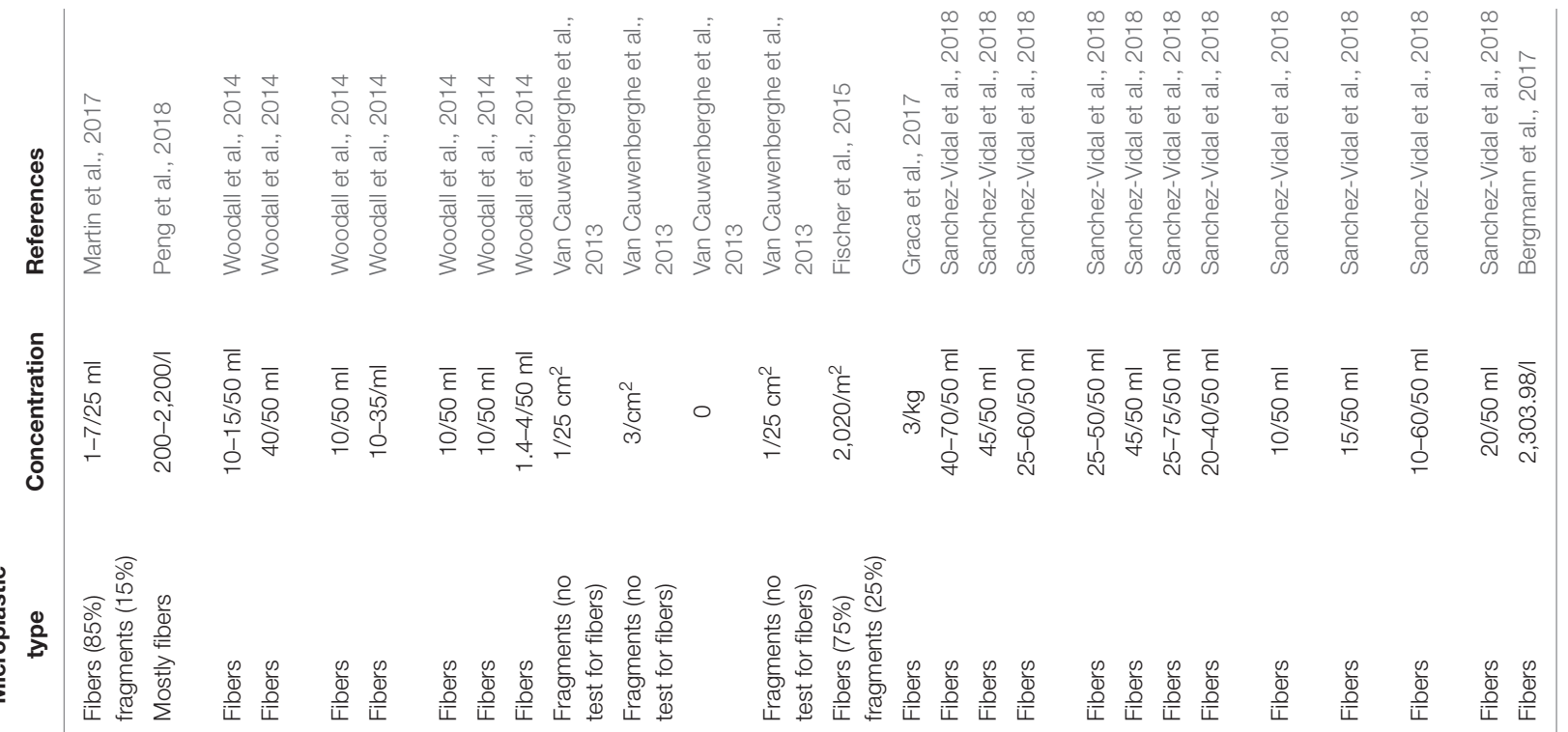

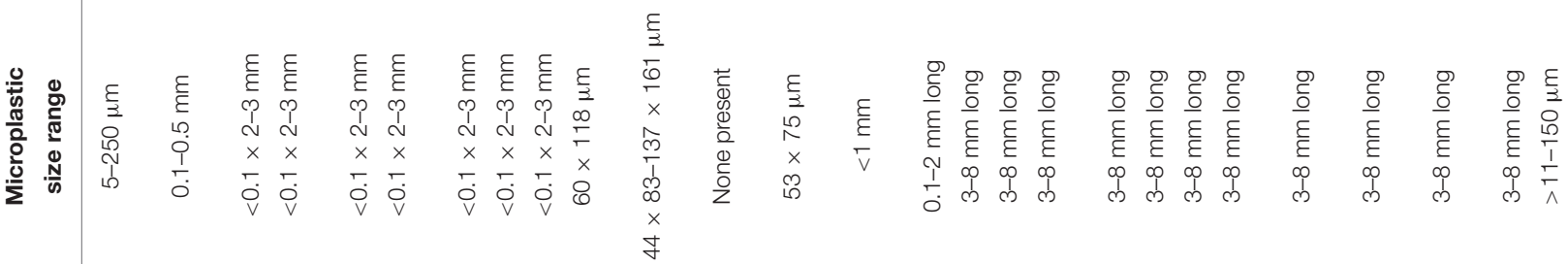

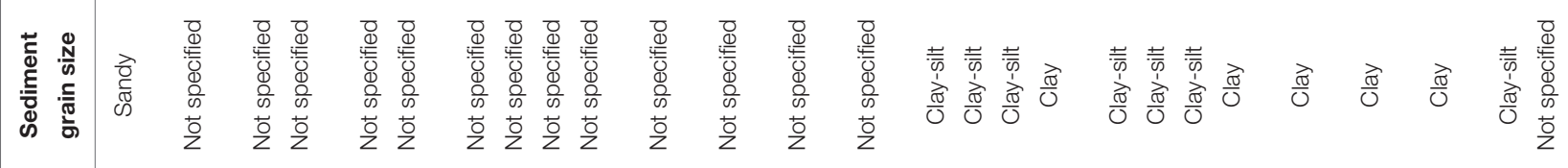

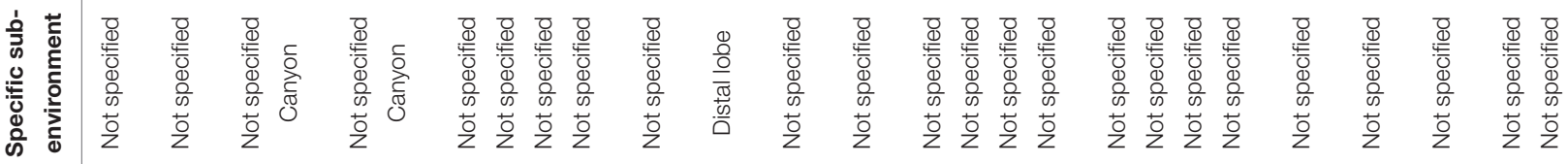

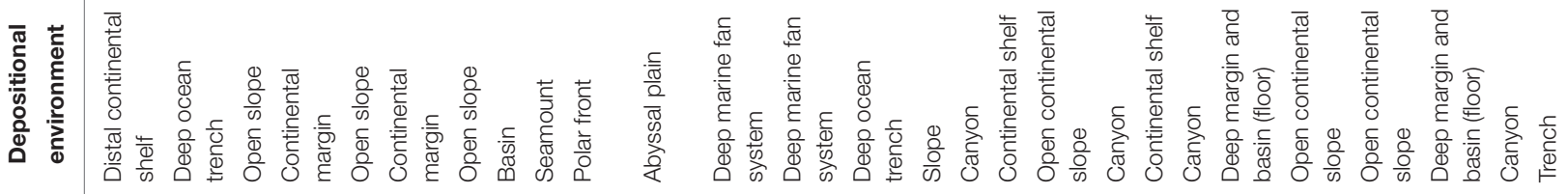

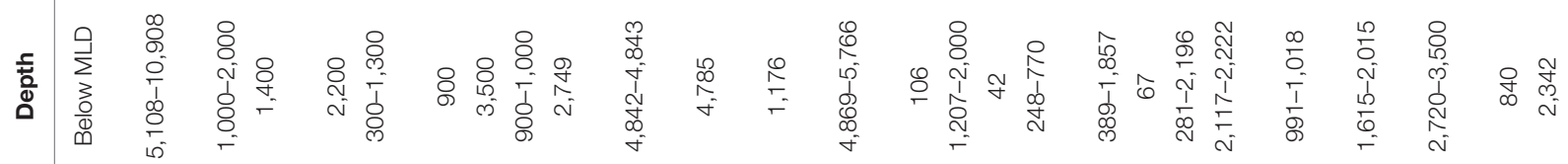




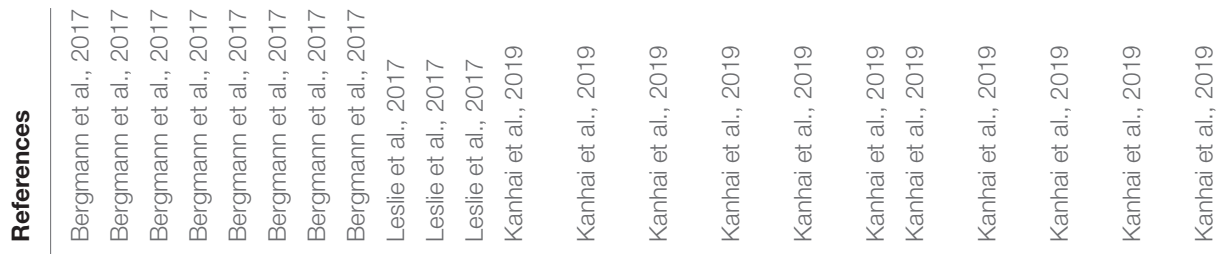

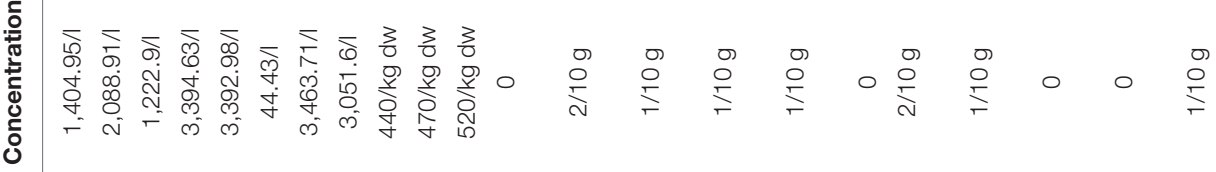

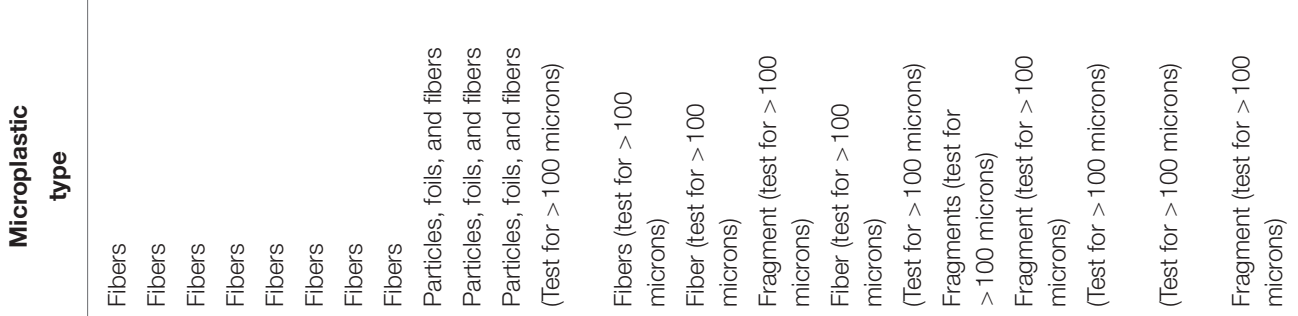

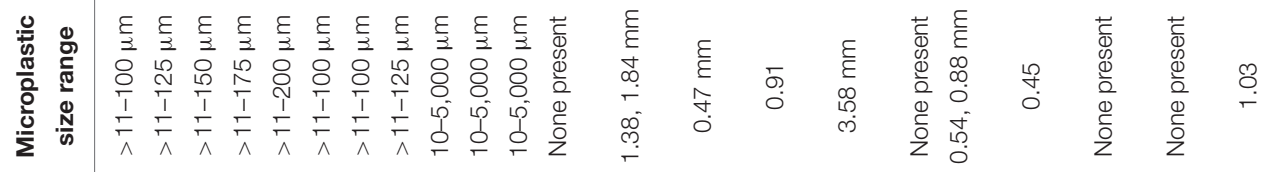

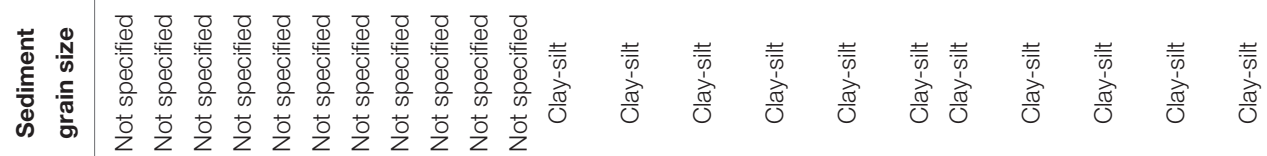

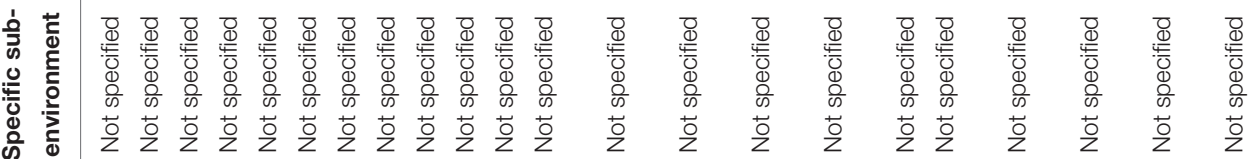

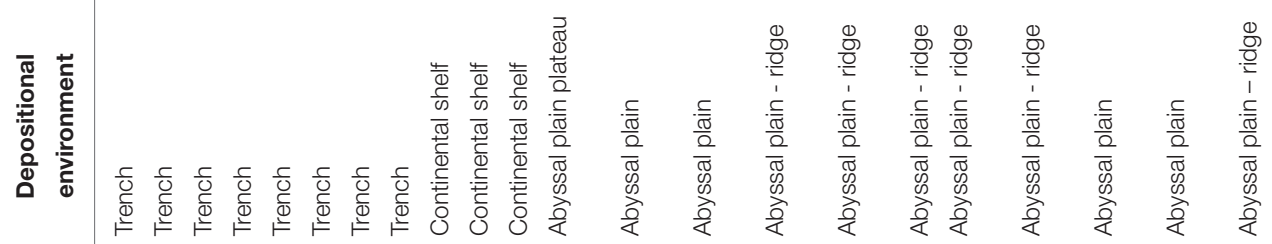

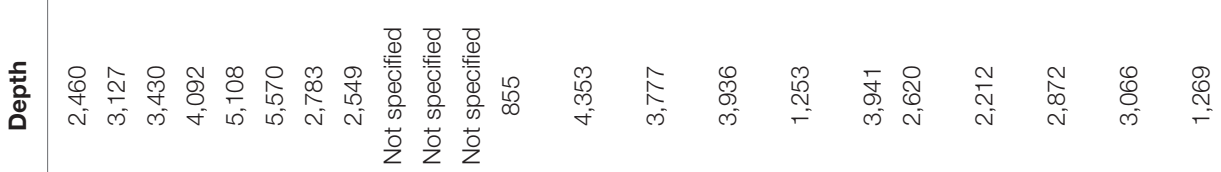

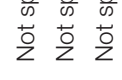

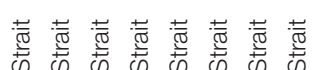

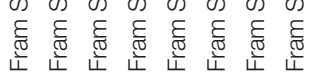
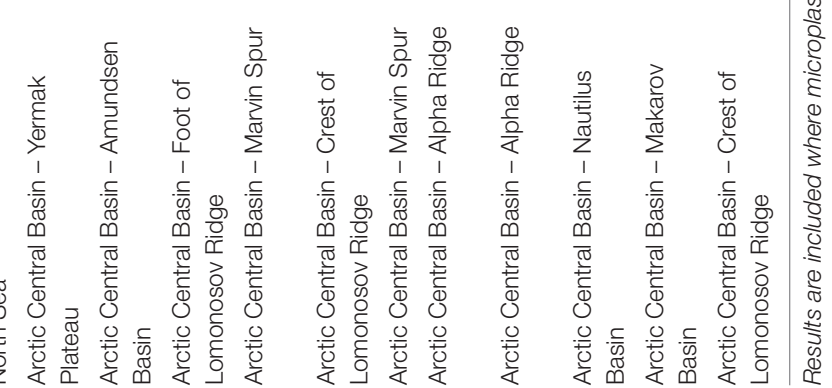
fluvial and shallow marine/tidal environments have started to address these issues, including the spatial, sedimentological, and temporal controls on microplastic distributions (e.g., Van Cauwenberghe et al., 2015; Hurley et al., 2018). We suggest that there is a pressing need to provide more detailed contextual information to link microplastics with the transport processes responsible for their accumulations in order to explain their distributions across different deep-sea depositional environments (Table 1 and Figure 4). If we ever hope to link microplastics to the processes that control their distribution in the deepsea, we must first understand how they are introduced to marine environments. The following section therefore first outlines the processes that transfer microplastics to the ocean, and then discusses how different tectonic, physiographic and oceanographic configurations may result in the wider dispersal or localized concentrations of microplastics.

\section{PROPERTIES OF MICROPLASTICS AND PHYSICAL CONTROLS ON THEIR SUSPENSION, TRANSPORT AND DEPOSITION}

Microplastics span a wide range of densities; from very low density, such as polystyrene $\left(40 \mathrm{kgm}^{-3}\right)$ to the densest, e.g., polytetrafluoroethylene $\left(2,020 \mathrm{kgm}^{-3}\right)$. In contrast, mineral sediment with a grain size larger than clay, i.e., silt and sand, delivered by rivers is dominated by quartz $\left(2,650 \mathrm{kgm}^{-3}\right)$, feldspar $\left(2,560 \mathrm{kgm}^{-3}\right)$, and mica $\left(2,750 \mathrm{kgm}^{-3}\right)$. Therefore, most of our understanding of sediment gravity flows on the seafloor is dominated by sand and mud transport, with less known about the behavior of lighter particles including microplastics, organic material such as plants, leaves and woody material (e.g., Zavala et al., 2012; Yamada et al., 2013). It is known that plant material can reach the distal parts of submarine fans, e.g., in Permian strata of Tanqua Karoo, Hodgson (2009) reported that plant material had been transported at least $150 \mathrm{~km}$ from the contemporaneous shoreline (where it was likely sourced). As well as particle density, grain shape plays an important role in the settling of grains from suspension, with platy particles, such as leaf fragments and mica (despite its high density), or those with intricate shapes, e.g., shells, typically settling more slowly than spherical particles (e.g., McNown and Malaika, 1950; Dietrich, 1982; Oehmig, 1993). Previous work has suggested the hydraulic 'equivalence' of organic material with 'platy' grains such as mica (Stanley, 1982), such that these particles often settle at lower velocities than slightly finer-grained siliciclastic sand and develop micaceous and organic rich caps to turbidite sand beds (e.g., Hodgson, 2009; Zavala et al., 2012) (Figure 7). Microplastics may exhibit a similar distribution and this would mean they are prone to erosion from subsequent flows, gradual down-system reworking, as well as erosion and resuspension
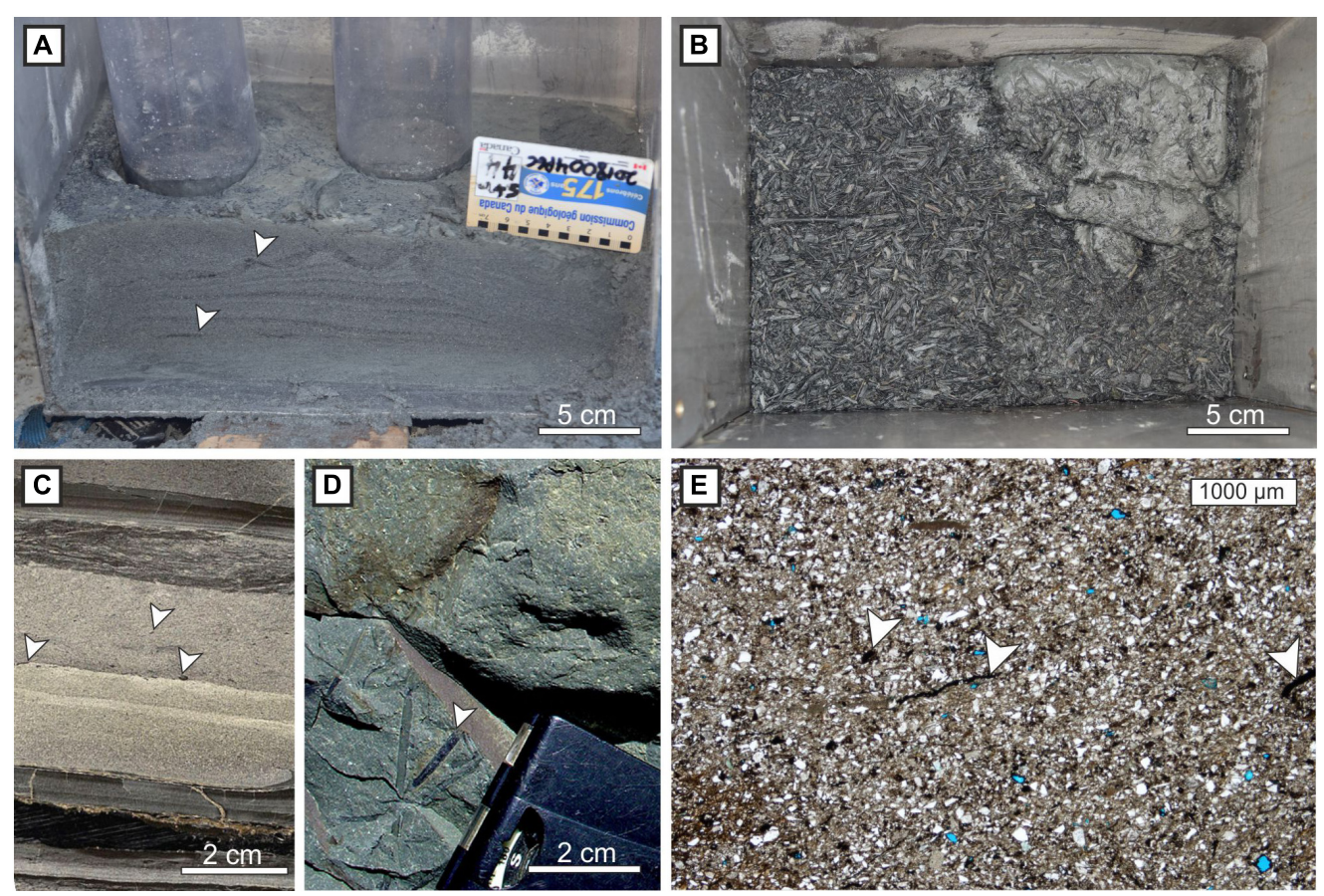

FIGURE 7 | (A) Organic-rich material incorporated within turbidite laminae, and (B) concentrated on the bed top; both from Bute Inlet, British Columbia (courtesy of Maarten Heijnen). (C) Organic material distributed within a hybrid bed and in the uppermost dark-colored division (cored interval, Palaeogene, Gulf of Mexico; Kane and Pontén, 2012). (D) Plant fragments in the upper part of a hybrid bed (Permian, Tanqua Karoo; Hodgson, 2009). (E) Thin-section photomicrograph showing small plant fragments within a hybrid bed (Permian, Tanqua Karoo; Kane et al., 2017). Microplastic fragments and fibers might be anticipated to have similar distributions in deep-water deposits. 
by bottom-currents which may flow obliquely to the 'primary' depositional system (Figure 3).

The principal candidates for the transport of microplastics to and across the deep seafloor are: (i) settling, or conveyance through biological processes, of material that was formerly floating on the surface or suspended in the water column; (ii) gravity-driven transport in sediment-laden flows, such as turbidity currents; (iii) reworking and transport by thermohaline currents; and (iv) internal tides (i.e., topographically steered internal waves that exhibit tidal frequencies; Shepard, 1975). We will now discuss the settling velocity of particles, and then consider the implications of these transport processes.

\section{Settling Velocities of Microplastic Particles}

The paucity of contextual sedimentological data in existing microplastics studies (Table 1) inhibits a detailed investigation of transport processes at present. Information on the specific depositional environment (e.g., a canyon axis that features regular turbidity currents versus an adjacent flank elevated above the zone of flow interaction) and critically the grain size of the host sediments are omitted in most of the existing studies. One of the few studies to provide grain size information (Maes et al., 2017) does not provide water depths or other environmental information for the samples collected. Despite the lack of observational data to link microplastics to transport process, a number of recent laboratory studies have made measurements of the settling velocities of microplastics such that we can investigate the anticipated range of processes and environments that control their transport, dispersal and/or concentration. Laboratory experiments to measure settling velocities for a range of plastic particles (Kowalski et al., 2016; Khatmullina and Isachenko, 2017) have demonstrated the expected deviation from theoretical values (e.g., following Dietrich, 1982). Settling velocities $\left(w_{\mathrm{s}}\right)$ for spherical particles within a turbulent flow can be estimated, following Ferguson and Church (2004), using $w_{\mathrm{s}}=\frac{R g D^{2}}{C_{1} v+\sqrt{0.75 C_{2} R g D^{3}}}$ where $R$ is the relative submerged density of the particles, $g$ is gravity, $D$ is the particle diameter, $C_{1}$ and $C_{2}$ are constants, 18 and 1, respectively. Relative submerged density $(R)$ is given by $(\rho s-\rho f) / \rho f$ where $\rho s$ is the density of sediment and $\rho f$ is the density of fluid, in this case seawater, at 1,026.2 $\mathrm{kg} \mathrm{m}^{-3}$. Settling velocities estimated for various microplastic particles are lower than the main 'sand-forming' minerals, which indicates that for a given size, plastic particles will be deposited later than sand grains (Figure 8). This means, for example, that a $0.5 \mathrm{~mm}$ diameter spherical polyurethane pellet would settle at approximately the same rate as a $0.15 \mathrm{~mm}$ diameter quartz grain (fine sand), or a $5 \mathrm{~mm}$ diameter pellet at the same rate as a $0.75 \mathrm{~mm}$ diameter quartz grain (coarse sand). Both natural and plastic particles have a range of shapes and surface roughness so these theoretical values (for spheres) typically over-estimate settling velocity.

Sediment particle size sorting occurs during deposition and resuspension according to the relationship of $w_{\mathrm{s}}$ to the fluid shear stress $(\tau)$ (either turbidity current or bottom current). In general the fluid shear stress for non-cohesive sediment deposition $\left(\tau_{\mathrm{d}}\right)$, is lower than that required for erosion $\left(\tau_{e}\right)$, which is lower still than that required for suspension $\left(\tau_{s}\right)$, such that $\tau_{d}<\tau_{e}<\tau_{s}$ (e.g., McCave et al., 2017). Plastic particle flocculation is poorly understood but it is assumed that most microplastics behave in a non-cohesive manner, however, they may be incorporated into larger aggregates when mixed with clay (Galgani et al., 2015) or when surfaces have accumulated biofilms (e.g., Lobelle and Cunliffe, 2011). Owing to their wide range of shapes, microfibers are anticipated to behave substantially differently to spherical (e.g., microbeads) or fragmented microplastics (e.g., Högberg et al., 2010). While there may be analogs with plankton fallout (Ptacnik et al., 2003; Peterson et al., 2005), plastic microfiber settling remains an area for future research (Kowalski et al., 2016; Khatmullina and Isachenko, 2017).

We now discuss some of the ways in which the preceding estimates of settling velocity may be modified, due to interactions of microplastics with the ambient marine environment.

\section{Enhanced Suspension Fall-Out Due to Reversing Buoyancy and Biological Modifications}

While many plastic particles start out with a given low density (and hence slow settling velocity), this can change over time as particles can: (i) accumulate biofilms (biofouling; e.g., Lobelle and Cunliffe, 2011; Muthukumar et al., 2011; Long et al., 2015; Cole et al., 2016; Fazey and Ryan, 2016; Kaiser et al., 2017); (ii) break down through UV light degradation (photodegradation; Shah et al., 2008); (iii) act as focal points for precipitation of chemicals and minerals on particle surfaces (Mato et al., 2001; Corcoran et al., 2015); (iv) undergo leaching of additives (Van Cauwenberghe et al., 2013, 2014 and (v) form aggregates of marine sediments (Galgani et al., 2015). Biofouling may explain the apparent lack of plastics on the sea surface; recorded levels of plastic at the surface are at least two orders of magnitude lower than anticipated (Cózar et al., 2014). Consumption of microplastic particles by organisms, such as polychaete worms, mysid shrimps and copepods can lead to the expulsion of microplastic-bearing fecal pellets with a greater density than initial microplastic densities (Kuo and Bolton, 2013; Setälä et al., 2014; Courtene-Jones et al., 2017), such that particles are prone to gravity driven settling in the water column. This mechanism has been demonstrated for enhanced settling flux of organic carbon in the Southern Ocean, due to its incorporation into the fecal pellets of krill (Belcher et al., 2019). Biological redistribution of microplastics may also occur through burial within sediment layers, by the burrowing action of organisms, or re-exhumation of previously buried microplastics at seafloor following its consumption and egestion (Urlaub et al., 2013; Näkki et al., 2017).

\section{Inhibited Settling Due to Thermohaline Stratification and Influence of Near-Bed Ocean Currents}

Little is known of the residence time of plastics on the sea surface, but it may be significant (>tens of years in some cases; Chubarenko et al., 2016). It has largely been presumed that the 


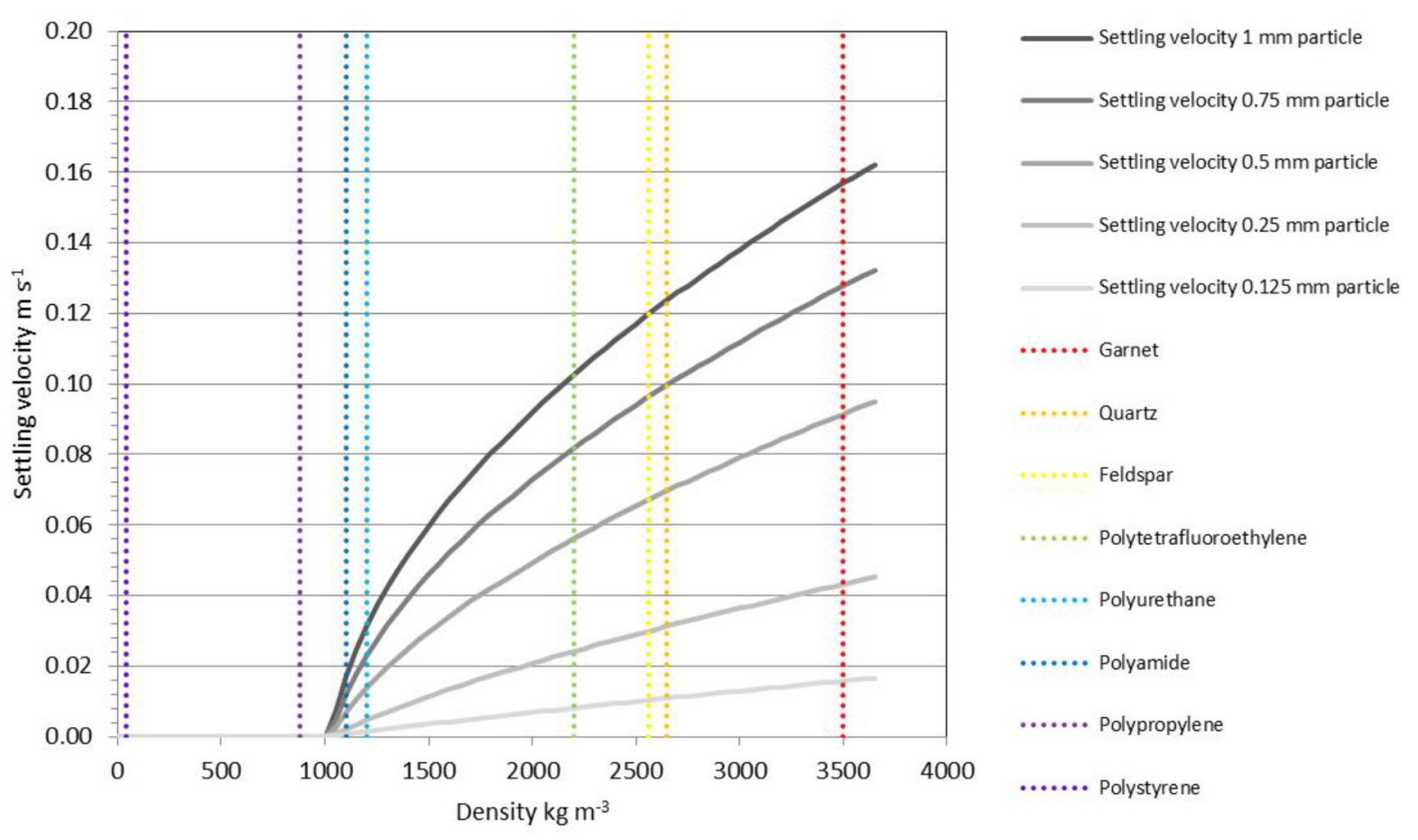

FIGURE 8 | Settling velocities estimated for a range of spherical particles in a turbulent flow; as an example a 1 mm polyurethane sphere would settle at similar velocity to a $0.25 \mathrm{~mm}$ quartz grain. Natural particles have a wide range of shapes and surface roughness which will affect their settling, and microfibers will diverge significantly from this model.

fallout of plastic from suspension will be concentrated in those areas prone to surface collection of particles as 'marine snow' (Wright et al., 2013); however, the influence of thermohaline circulation in the ocean must not be ignored. Thermohaline stratification can create nepheloid layers that inhibit fall-out and promote the lateral advection of fine sediments, while bottomhugging contour currents can be agents of sediment deposition, bypass and reworking, and can develop very large accumulations of fine-grained sediment, known collectively as drift deposits (e.g., Stow and Lovell, 1979; Rebesco et al., 2014).

Settling of microplastics to the seabed will only occur when the shear stress at the base of a flow is lower than the settling velocity, thus leading to inhibited settling and advection of microplastics. Given the typical velocities of near-bed thermohaline currents in many deep-sea locations worldwide $(\sim 0.1-0.4 \mathrm{~m} / \mathrm{s}$; McCave et al., 2017), it is not surprising that thermohaline currents have been implicated as a control on microplastic transport in several locations in the deep-ocean (Fischer et al., 2015; Bergmann et al., 2017; Peng et al., 2018). Microplastics and fibers in the KurilKamchatka Trench (Table 1) have no immediately adjacent source area, and it has been suggested that northwards-flowing bottom currents in the trench could have brought material from Japan and from as far afield as Russia (Peng et al., 2018). Thermohaline currents have also been invoked for the transport of microplastic particles into the deep Fram Strait (Arctic Sea) owing to its distance from an obvious source (Bergmann et al., 2017) (Table 1). Where a stratified water column interacts with pronounced seafloor topography, internal tides often develop in response to surface tides. Internal tides can exert pronounced shear stresses at seafloor and play an important role in the modulation of downslope sediment transport processes; often acting to re-suspend and transport sediment within canyons and other areas of enhanced relief such as seamounts (e.g., Inman et al., 1976; Paull et al., 2005; Lee et al., 2009; Zhao et al., 2012). In a numerical modeling study of microplastic transport within the Nazaré Canyon (NE Atlantic), internal tides were found to resuspend and move microplastics both up and down canyon, with only a minor net-downstream movement (Ballent et al., 2013). It might be anticipated that one of the main effects of internal tides is to continuously re-suspend the lightest particles deposited on the seafloor priming them for entrainment by large gravity currents moving down the canyon (see Section "Modified Settling in Sediment-Laden Fluids and the Importance of Sediment Gravity Flows"). Current-related deposits, in particular contourite drifts, may account for large quantities of microplastics, however, this cannot yet be discerned from existing published studies (Table 1).

\section{Modified Settling in Sediment-Laden Fluids and the Importance of Sediment Gravity Flows}

Analysis of microplastic settling has so far been determined within clear fluids (Kowalski et al., 2016; Khatmullina and Isachenko, 2017). Given the global importance of gravity-driven flows in the transport of sediment and other hydrodynamically 
light particles in the deep-sea (Galy et al., 2007; Talling et al., 2012a; Gwiazda et al., 2015; McArthur et al., 2017), further work is needed to understand the behavior of microplastic particles in sediment and fluid flows. Such work has been performed for mud and sand mixtures (e.g., Amy et al., 2006) but not yet for mixtures including microplastics, and will need to incorporate the spectrum of gravity flows; from turbidity currents (Talling et al., 2012a), to debris flows (e.g., Mohrig et al., 1998; Ilstad et al., 2004; Talling et al., 2012a,b; Baker et al., 2017), and slumps and slides which feature a lower degree of internal disaggregation than debris flows (e.g., Nardin et al., 1979; Booth et al., 1993; Masson et al., 2006; Talling et al., 2012b). This work will be important for the consideration of microplastic distribution within sediment gravity flow deposits (i.e., distributed throughout the bed versus on top of the bed), as this will impact the likelihood of long-term burial rather than erosion by the next gravity flow event.

Sediment gravity flows (in particular turbidity currents) may be significant agents for transporting and distributing microplastics in the deep sea. The first reason is that such flows will entrain and transport microplastics whose density is greater than that of seawater, or that are incorporated in a dense sediment suspension (Ballent et al., 2013; Schlining et al., 2013; Tubau et al., 2015; Zalasiewicz et al., 2016). Thus in a deep-sea system, such as a submarine canyon where gravity-driven flows typically decrease in energy both spatially and temporally, lower density/finer grains can be transported further than higher density/coarser grains, and tend to be deposited later at a given point, as has been shown for low density particulate organic carbon (e.g., Zavala et al., 2012; McArthur et al., 2017; Paull et al., 2018). The second reason relates to how and where sediment gravity flows initiate (i.e., often close to sites of significant terrestrial sediment dispersal such as rivers and/or are foci for the trapping alongshelf sediment transport). Turbidity currents are generated in two principal ways: firstly, by direct fluvial input of sedimentladen river water outflow, which either plunges as it debouches from the river mouth as a hyperpycnal flow (Mulder and Svytski, 1995; Mulder et al., 2003) or settles out from a lower density surface plume (Kineke et al., 2000; Ayranci et al., 2012; Hizzett et al., 2018) to trigger a turbidity current. Such flows have been shown to be significant for transferring organic carbon to deepwater, due to the direct connection of river outflow, and hence are also likely to be important for microplastics transfer (see section "In Which Physiographic Domains Have Microplastics Been Documented to Accumulate at Seafloor?"; Galy et al., 2007; Zavala et al., 2012; Sparkes et al., 2015). Secondly, turbidity currents may form due to externally or autogenically triggered collapse of sediment accumulations, such as at submarine canyon heads that trap littoral sediment transport (e.g., Xu et al., 2002; Paull et al., 2018; Smith et al., 2018), rapidly prograding delta fronts (e.g., Clare et al., 2016; Obelcz et al., 2017) or on open continental slopes (e.g., Nisbet and Piper, 1998; Talling et al., 2014; Soutter et al., 2018). Such failure-generated flows may be highly concentrated, contain a heterogeneous sediment mixture, and have the potential to run-out significant distances, eroding and entraining seafloor deposits from open slopes, or within a canyon or channel along their path (e.g., Piper and Savoye, 1993;
Stevenson et al., 2015; Allin et al., 2016; Hunt, 2017; Mountjoy et al., 2018).

\section{Where Should We Expect Microplastics to Be Deposited Within Individual Deep-Sea Deposits?}

To date, there has been little to no work done on the vertical distribution of plastics within depositional units. Most samples collected have been from the top few centimeters of sediment and, presumably (although the information is generally not given), from relatively fine grained (clay-silt) deposits. Despite these limitations, our understanding of particulate density fractionation during transport and deposition provides a basis for an initial predictive assessment of their distribution within individual deposits. From the ancient record (e.g., Kneller and Branney, 1995; Talling et al., 2012b) and from observations in modern environments (e.g., Smith et al., 2007; Biscara et al., 2012; Clare et al., 2017; Hage et al., 2018; Mountjoy et al., 2018; Stevenson et al., 2018) we know that some individual event deposits (e.g., by gravity flows) can be many meters thick; hence, the assertion that plastics are only present in the first few centimeters of sediment below the seafloor is unlikely to hold (c.f. Martin et al., 2017). In the following section, we discuss how initial depositional processes may govern the depth below seafloor at which different types of microplastics accumulate, first focusing on episodic gravity flows and then on longer duration, more persistent ocean currents.

\section{Gravity Flow Deposits}

It has been suggested that turbidites will show sorting of plastic fragments based on their density, size and shape, with plastic fragments concentrated in the upper divisions (C-E) of 'Bouma (1962) type' turbidites (Zalasiewicz et al., 2016). Zalasiewicz et al. (2016) also suggest that plastic fragments may behave in a similar way to other non-spherical particles within sandy deposits (e.g., robust shell fragments, which typically end up in the bottom parts of beds while less dense shells are typically concentrated a little higher, in the ripple-laminated Bouma C division; Davies et al., 1997). In a turbidity current, particles settle according to their density and shape, such that particles with high settling velocities (e.g., dense, spherical particles) will tend to settle faster than those with low settling velocities (e.g., low density, platy particles or fibers). Accordingly, grains with higher settling velocities will tend to concentrate at the base of the flow, whilst those with lower settling velocities will be distributed throughout the flow, due to turbulent mixing (Figure 9). Flows that are forced to decelerate rapidly, either due to being overloaded with sediment or due to topography, will tend toward having high sediment fallout rates as the turbulent energy dissipates, and the deposit will reflect the stratification of the flow at that point. Where flows decelerate less rapidly (e.g., less concentrated flows running out over gradually decreasing slopes), the turbulent kinetic energy dissipates more slowly, such that particles with progressively lower settling velocity drop out of the flow (e.g., Kneller, 1995). The former case leads to the development of thick, poorly sorted, massive to crudely stratified 


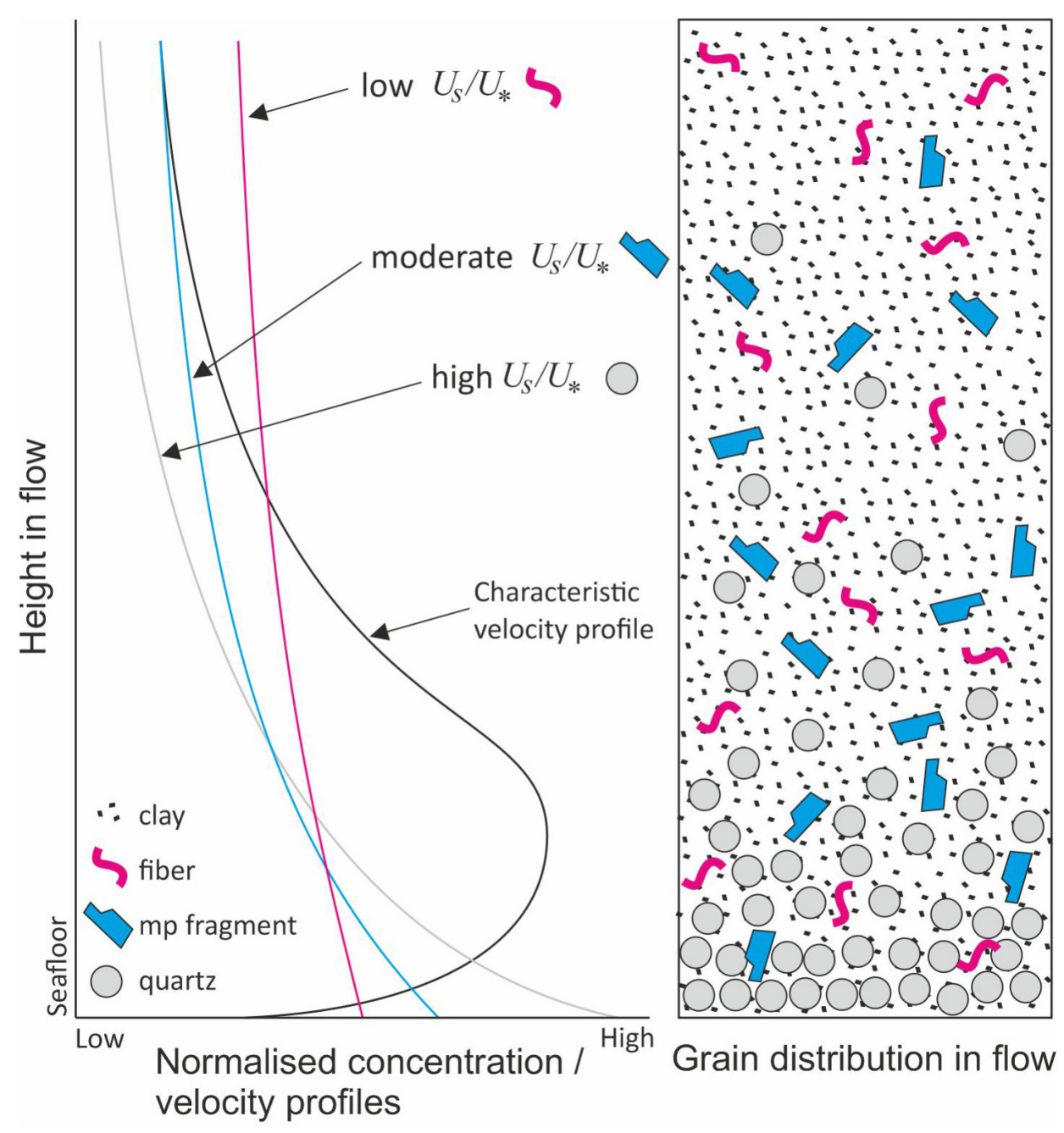

FIGURE 9 | Sediment distribution in a turbidity current. Particles with a relatively low settling velocity $\left(U_{\mathrm{s}}\right)$, in comparison to the shear velocity $\left(U_{*}\right)$, e.g., microplastics, will tend to be more homogenously distributed throughout the flow than those with a high settling velocity, e.g., quartz and feldspar. $U_{s}$, settling velocity; $U_{*}$, shear velocity. Where microplastics end up in the flow deposits depends on the rate of flow deceleration, e.g., they might be distributed throughout high-density turbidites, but concentrated at bed tops in low-density turbidites. Modified from Hansen et al. (2015).

turbidites (i.e., 'high density turbidites'; Lowe, 1982; Kneller, 1995; Kneller and Branney, 1995; Baas and Best, 2002), while the latter produces a well-developed normal-grading grain-size trend and parallel- to ripple-laminated deposits (i.e., 'low density turbidites'). Consequently, microplastics in these flows will be distributed throughout beds according to these factors. In high density turbidites, microplastics may be distributed throughout the bed, which may be several meters (or more) thick. In low density turbidites, microplastics may be concentrated at the bed tops (Figure 9). This has a consequence for the likelihood of microplastic remobilization by subsequent turbidity currents, for sampling methodology (as most studies sample only the uppermost few centimeters of beds), as well as the availability of microplastics to ingestion by seafloor and/or burrowing fauna (Wright et al., 2013). In situations where a flow is constrained by topography (e.g., within a channel), the upper part of the overspilling flow will tend to concentrate particles that have a low settling velocity (e.g., Kane et al., 2007; Hansen et al., 2015, 2017; McArthur et al., 2017), making depositional areas such as levees more likely sites for microplastics accumulation. A summary of deep-marine gravity flow deposit types and likely microplastic distribution is presented in Figure 10.

\section{Ocean Current-Related Deposits}

Deposits related to ocean currents interacting with the seafloor (i.e., 'bottom currents'), form a wide range of morphologies grouped together into 'drifts.' The large drift deposits observed globally are built from sediment that was initially delivered by gravity flow systems, but subsequently reworked by bottom currents. This suggests that microplastics delivered to the basin floor by gravity currents may be prone to erosion and transport by bottom currents, and eventually be sequestered within drift deposits (Rebesco et al., 2014). Drift deposits are generally fine grained, clay-silt, and may reflect current strength 


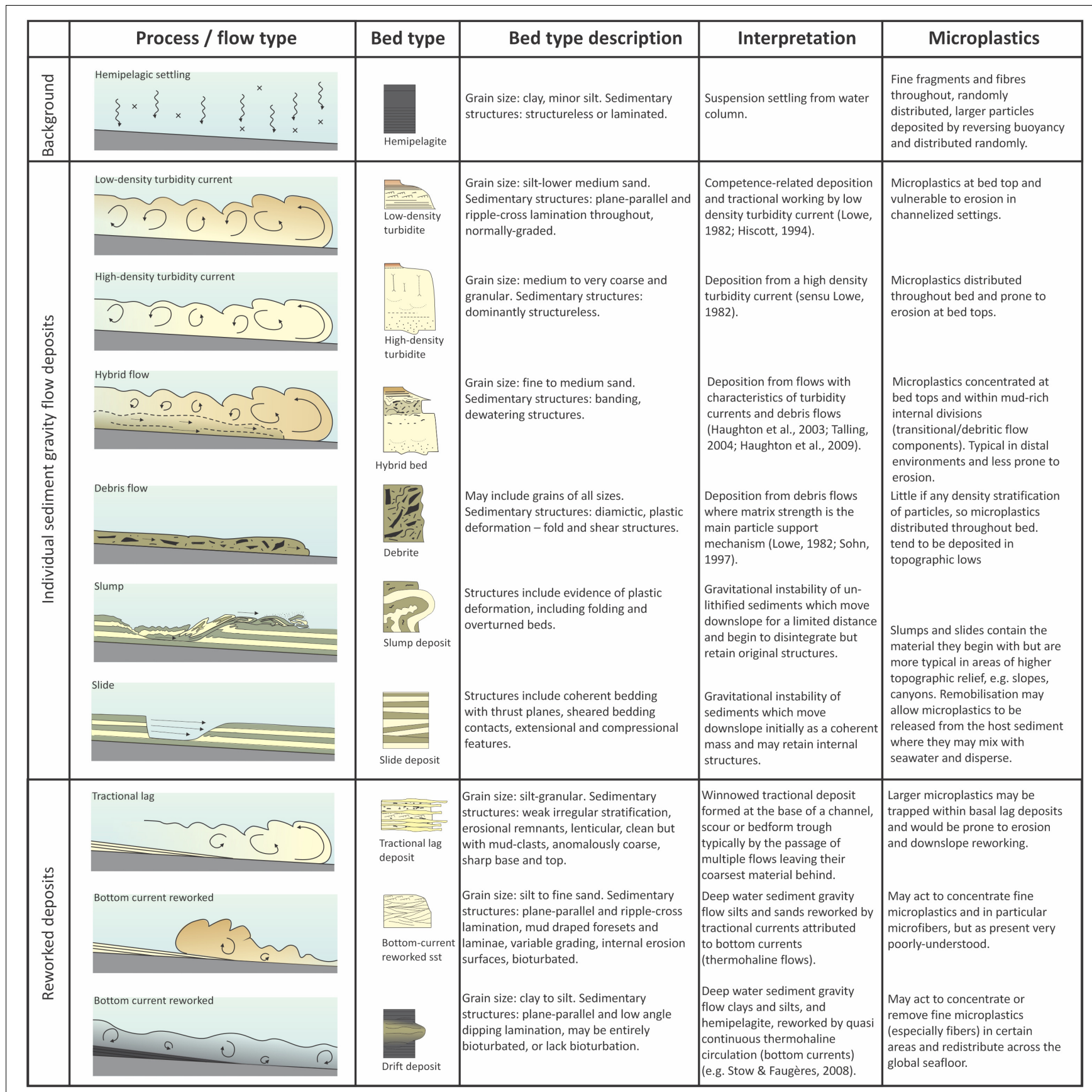

FIGURE 10 | Range of sediment gravity flow types, their deposits, and the anticipated distribution of microplastics. This is important as specific benthic ecosystems develop in depositional sites prone to particular sediment gravity flow types; the deposit type then has a bearing on the likelihood of remobilization of microplastic and its availability for ingestion by benthic fauna.

variability through time (e.g., Stow, 1991) (Figures 9, 10). The persistent nature of bottom currents, although they may show seasonal variation, means that their deposits are often relatively homogeneous with less well-defined beds than typical gravity current deposits, which tend to be related to episodic events. The velocities of bottom currents $\left(0.06-0.5 \mathrm{~ms}^{-1}\right.$; e.g., Ridderinkhof et al., 2010; McCave et al., 2017; Miramontes et al., 2019) could easily provide enough shear stress to transport microplastics, in particular fibers. Drift deposits are often sites of intense bioturbation and this could be a pathway for microplastics into the deeper sediment (as well as preferentially ingested by benthic organisms). The exceedingly thick and stratigraphically continuous drift deposits preserved offshore east and west Africa, east of South America (e.g., Faugères et al., 1993; Rebesco et al., 2014), and elsewhere, demonstrate the high preservation potential of these features. We anticipate drift deposits to be 
significant sites for microfiber concentration and storage in the sedimentary record (Figures 3, 9).

\section{IMPLICATIONS FOR THE LONG-TERM DISTRIBUTION OF MICROPLASTICS WITHIN DEPOSITIONAL SETTINGS AND THEIR ULTIMATE FATE}

The arrival and storage of microplastics in the Earth's stratigraphic record has been suggested to mark the onset of the Anthropocene as a new geological epoch (e.g., Waters et al., 2016; Zalasiewicz et al., 2016). In the longer (geological) term, plastics will not be preserved but the breakdown of various types of plastics in seawater, at varying depths, salinities and levels of UV penetration, is poorly understood. However, it is considered that microplastics deposited in the benthic realm may breakdown more slowly than at the land surface, due to the lack of UVradiation, colder temperatures and lower oxygenation (Woodall et al., 2014). We now revisit the global deep-sea distribution based on understanding of initial influxes, and processes that govern their transport. We integrate recent findings from repeat surveys and direct monitoring of sediment transport to try and understand how future microplastic distribution may change.

\section{Open Continental Slopes}

Open continental slopes are here described as the inter-canyon, predominantly non-channelized parts of the clinothems which form the slope between the continental shelf and the base of slope/basin floor. The nature of the tectonic setting will determine the size and the angle of the slope, and the width of the continental shelf, and hence the delivery of sediment to the shelf edge. Continental slopes are generally sites of steady sediment accumulation; microplastic accumulation may be pervasive where sediment is fed along the continental shelf by longshore currents. Submarine landslides may deliver very large volumes $\left(>>1 \mathrm{~km}^{3}\right)$ of sediment to the base of the slope, some of which may transform into turbidity currents (Nisbet and Piper, 1998; Urlaub et al., 2013). These events may be a way of exhuming large volumes of microplastics which have accumulated over many years, and delivering them to the base of slope and beyond. Factors influencing the development and size of submarine landslides include the sedimentation rate, and the tectonic regime, for example small regular earthquakes may continuously shed sediment from the slope, whereas large infrequent events may remove much larger volumes. Slope reworking may occur during periods of enhanced bottom current activity, and open continental slopes are often sites of large drift mounds. Dense water cascades from the shelf, due to trawling and seafloor mining activity, are also common (Palanques et al., 2001; Shapiro et al., 2003). Submarine landslides and debris flow deposits are not restricted to active margins, they can also be common in passive margin settings, for example Eastern United States, NW African, and Norwegian margins (e.g., Masson et al., 2010; Hodgson et al., 2018b). Open slopes are thus generally considered to be sites for accumulation of fine microplastics, in particular fibers, and advection from the coast is dependent on the shelf width, location of canyons, and prevalence of longshore currents. Reworking by ocean currents may result in along-slope redistributions in drifts that reflect the trend and intensity of near-bed bottom currents. Submarine landslides may be relatively infrequent, but can serve to re-exhume large areas of previously sequestered microplastics and redistribute them further down-slope.

\section{Submarine Canyon-Channel-Lobe Systems}

\section{Submarine Canyons}

Submarine canyons are common features along continental margins, usually occurring seaward of major rivers (e.g., Shepard, 1955). They are large-scale erosional features incised into the shelf and slope that commonly have a V-shaped cross section, particularly in the upper reaches (e.g., Pickering et al., 1989). Toward the continental rise (at the base of the slope), canyons flare out and become less steep. Canyons occur across a wide range of scales, from tens to hundreds of kilometers wide, extending downslope for distances of tens to hundreds of kilometers (Pickering et al., 1989). The canyon head may lie within a couple of hundred meters off the coastline (e.g., Monterey Canyon, Paull et al., 2005) or may not extend onto the shelf at all (e.g., Orange et al., 1997), while the canyon mouth may feed one or more submarine channel-levee systems or fed directly into a submarine fan.

Studies of modern canyon systems and linked deep-water fans, such as the Congo canyon, have shown that sustained turbidity currents are very efficient transporters of organic material into deep-water, with organic material often reaching the most-distal parts of the fan (Khripounoff et al., 2003; AzpirozZabala et al., 2017). Turbidity currents in the Congo canyon are estimated to contribute $2 \%$ of terrestrial organic carbon buried globally in the oceans, with individual flows delivering up to 0.19 Megatons of organic carbon. Such flows could therefore be highly capable of transporting microplastics, being of similar densities to organic material, to the distal parts of the fan. This organic material, together with relatively oxygenated water, is important for benthic ecosystems at extremely deep water depths (Rabouille et al., 2017). Similar distributions of organic material are recorded in ancient submarine fan systems (e.g., Stanley, 1982; McArthur et al., 2017). Other anthropogenic pollutants such as DDT pesticide have been demonstrated to preferentially flow down canyons. In the Monterey Canyon, Paull et al. (2002) documented levels of $10 \pm 3$ to $18 \pm 8 \mathrm{ppb}$ in the canyon, but only $2 \pm 2 \mathrm{ppb}$ in the intra-canyon flanks and background slope.

Large magnitude flows within canyons, e.g., due to large earthquakes, can result in 'flushing' of sediment that has accumulated within them (Piper and Savoye, 1993; Talling et al., 2013; Allin et al., 2016; Fildani, 2017; Mountjoy et al., 2018). This includes canyon muds and other deposits including levees, terrace and channel fill. If terrace deposits and levees are sites of preferential storage of deep-marine microplastics, as recent studies have suggested, then this flushing would potentially remobilize microplastics that are temporarily stored in these environments. Given the rates of decay cited for plastic 
degradation, many of today's plastics may be around from $10 \mathrm{~s}$ to upward of 1,000 years and consequently a large canyon flushing event could release a huge amount of non-degraded microplastic. Recent work on river transported microplastic has shown that flood events may flush river-bed microplastics; in the Mersey catchment (United Kingdom), winter flooding removed approximately $70 \%$ of the microplastic load stored in riverine sediments, and entirely removed microbeads at seven sites (Hurley et al., 2018). Whether all of this sediment was transported downstream or lighter particles were also delivered to the overbank, is unclear. Microplastics are anticipated to be equally prone to flushing in submarine environments. Highresolution seafloor surveys performed before and after a powerful $\left(>7 \mathrm{~ms}^{-1}\right)$ turbidity current in the Monterey Canyon revealed that only the sandy axial channel (100-200 m width) was subjected to significant erosion ( $>3 \mathrm{~m}$ in places), while the more muddy canyon flanks showed no resolvable elevation difference (Paull et al., 2018). Thus, the influence of canyon flushing may be quite focused, ensuring more effective long-term microplastic sequestration in overbank areas.

Recent work focused on the distribution of different sediment gravity flow deposit types has shown that those with internal divisions of homogenous sediment deposited by transitional or laminar flow (e.g., hybrid beds), tend to occur in distal lobe settings that are less prone to erosion (e.g., Haughton et al., 2003), suggesting that plastics may be retained in the sedimentary deposit. In contrast, turbidites deposited within canyon or channel axes, that feature concentrations of lighter particles at the bed tops (e.g., low density turbidites), are prone to remobilization (e.g., Symons et al., 2016; Hage et al., 2018). The timescales of remobilization will depend upon the frequency and magnitude of successive seafloor flows.

\section{Submarine Channels}

Submarine channels are long-term conduits for sediment transport and extend from the canyon into the deeper basin, and terminate in lobe deposits beyond the channel mouth (Normark, 1970; Pickering et al., 1989; Mutti and Normark, 1991; Normark et al., 1997; Peakall et al., 2000; Jobe et al., 2015; Hansen et al., 2017). Channels may be bound at their margins by erosional surfaces or levees, or both (e.g., Clark and Pickering, 1996; Li P. et al., 2016). As much of their lifespan is dominated by bypass of turbidity currents, the deposits preserved at channel bases tend to be coarser particles and transient bedforms (e.g., Symons et al., 2016; Hunt, 2017; Hage et al., 2018). Microplastics will be both bypassed through the channel and spill over onto the internal levees and terraces, within a wider channel belt, and also onto the external levees bounding the channel system (Kane and Hodgson, 2011). Internal levees and terraces have moderate preservation potential but may still be prone to erosion by, and entrainment into large flows. External levees tend to have better preservation potential as overspilling flows tend to be relatively dilute (e.g., Piper and Normark, 1983). Vendettuoli et al. (2019) showed that over just 1 year, the average preservation of deposits across the active river-fed (fjord) Squamish submarine channel system was $11 \%$, with much lower preservation in proximal parts of submarine channels, at the eroded flanks of channel bends, and at the channel-lobe transition zone (as low as $0 \%$ preservation). In thick turbidites of the same system, erosion by repeated turbidity currents tended to leave only the lowermost and coarsest fraction of individual beds in the channel axis, hence any other fines are reworked (Hage et al., 2018). On an even larger scale, intrachannel erosion by upstream-migrating knickpoints has been shown to result in poor preservation potential of deposits in the channel axis, while terraces and levees were sites of enhanced deposit preservation (Gales et al., 2018). In summary, channel axes are considered to be important conveyors of and temporary storage sites for microplastics, but it is levees and terraces that are the most likely hotspots for their long-term accumulation. To date there are no known studies of microplastics in this setting.

\section{Submarine Lobes}

Lobes represent the terminal parts of deep-water sediment routing systems and are repositories for the vast amount of mainly siliciclastic sediment transferred by channel systems (Normark, 1978; Walker, 1978; Nelson et al., 1992; Twichell et al., 1992; Gervais et al., 2006; Deptuck et al., 2008; Jegou et al., 2008; Saller et al., 2008; Prélat et al., 2009). Lobe bodies typically thin and become more fine-grained away from the feeder channel. The upper surfaces of lobes, in particular the distal parts, are commonly covered by mud and organic material transferred through the system (Figure 7). Repeated turbidity current activity on a lobe means that this lighter material will ultimately end up at the most distal parts of the lobe. Sedimentary facies broadly evolve from thick high density turbidites at the lobe axis, to thin low density turbidites at the lateral and distal fringes (e.g., Johnson et al., 2001; Hodgson et al., 2006). Transformation of turbidity currents into dense cohesive flows is common in these settings, as the fine cohesive material left on the seafloor is picked up and incorporated into incoming turbidity currents (Haughton et al., 2003; Hodgson, 2009; Talling et al., 2013; Kane et al., 2017; Southern et al., 2017; Spychala et al., 2017; Fildani et al., 2018). The deposits of these flows (hybrid beds) typically have an ungraded muddy-sand division which is rich in organic material; microplastics may be incorporated into these internal divisions and, being in a distal locality are less likely to be eroded by subsequent flows.

Repeated surveys of the submarine channel system in Lake Geneva indicate that, over a period of 125 years, channel-levees and the distal lobe account for $75 \%$ of stored sediment delivered to the system, but $52 \%$ of this was transported further toward more distal locations ( $16 \%$ of that was stored in the levees, and $37 \%$ on the lobe; Silva et al., 2018). Consequently, a significant proportion of sediment supplied by rivers ended up at the terminal lobe. This is similar to observations from the Squamish submarine channel system, where the lobes are generally sites of net accumulation (Hizzett et al., 2018; Vendettuoli et al., 2019). Overall, the distal fringes of lobes in major submarine sediment routing systems are considered to be likely hotspots for microplastic accumulation.

\section{Abyssal Plains and Deep-Sea Trenches}

The abyssal plain lies beyond the base of the continental slope, downslope of major submarine sediment routing systems. 
Sedimentation rates are generally very low and dominated by pelagic settling, but in some cases influenced by the action of bottom currents (see section "Where Should We Expect Microplastics to Be Deposited Within Individual DeepSea Deposits?"), or interrupted infrequently by basin-wide emplacement of turbidites that initiated as submarine landslides (e.g., Rusnak and Nesteroff, 1963; Weaver and Rothwell, 1987; Clare et al., 2014). It has been suggested that bottom currents may transport plastics, particularly fibers, but the deposition of microplastics that have undergone biofouling or UV light degradation might be significant, as well as marine litter from shipping and fishing. Some of the samples analyzed by Van Cauwenberghe et al. (2013), Woodall et al. (2014), and SanchezVidal et al. (2018) may be ascribed to the abyssal plain but the limited depositional context renders any further sedimentological analysis somewhat challenging.

The deepest reaches of the world's oceans, deep-sea trenches, occur along subduction plate boundaries and are sites of sediment accumulation. Deep-sea trench sediments have been shown to host disproportionately high quantities of microplastics (Fischer et al., 2015; Bergmann et al., 2017; Peng et al., 2018). Notably, Fischer et al. (2015) recorded plastic microfibers at depths of up to $5,766 \mathrm{~m}$ in the Kamchatka Trench and abyssal plain, with concentrations as high as 2,000 $\mathrm{m}^{-2}$, and Peng et al. (2018) discovered microfiber levels as high as 1,600 pieces per liter of sediment at 10,903 m depth in the Mariana Trench. As these trenches are located large distances from any direct input, bottom currents and water column settling are considered to be the dominant processes for their transfer, but input arising from adjacent trench-slope failures may also make rare but significant contributions. Thin-skinned (cm-thick) but areally widespread slope failures have been shown to introduce large quantities of sediment $\left(>0.1 \mathrm{~km}^{3}\right)$ and organic carbon $(>1 \mathrm{Tg})$ to the Japan Trench (Kioka et al., 2019); hence might also be expected to remobilize previously buried microplastics.

\section{Preservation Potential Summary}

In general, proximal and high-energy environments, such as canyon and channel axes, are sites of sediment bypass rather than long-term storage (Stevenson et al., 2015). Microplastics in these settings will be transient and subject to downstream reworking. In areas where flows decelerate, and die out, such as on levees, terraces, and lobes, sediments and microplastics may be stored for longer time periods, or indefinitely. In the recent study of Martin et al. (2017), a depth of $4 \mathrm{~cm}$ was recommended to capture all of the microplastics in a deep-marine setting, however, in many deep-marine settings, microplastics may be much more deeply buried and the depositional environment needs consideration. No single rule fits all environments. For example, on the flanks of the upper Monterey Canyon, in their study of DDT pesticide distribution, Paull et al. (2002) recorded sedimentation rates of $0.6 \mathrm{~cm} /$ year; if no erosion took place since plastic production began, there may be areas where sediment thicknesses of $40 \mathrm{~cm}$ plus contain microplastics. In areas where large sandy turbidity currents are active, microplastic-bearing deposits may be tens of meters thick. Little is known regarding the transport of microplastics by bottom currents, but it seems highly likely that they are important agents for the redistribution of sediment gravity flow delivered microplastics across the global seafloor. Quiescent settings such as abyssal plains, and deep-sea trenches in particular, feature high preservation rates and are likely to be long-term deep-sea depositional sinks for microplastics.

\section{Implications for Benthic Ecosystems}

Despite their prevalence, the implications of the presence of microplastics on the seafloor are poorly understood - but it is thought that they are entering the food-chain via trophic transfer from benthic organisms (Ivar do Sul and Costa, 2007; Lusher, 2015; Rochman, 2015; GESAMP, 2016; Li W. C. et al., 2016; Taylor et al., 2016; United Nations Environment Programme [UNEP], 2016; Courtene-Jones et al., 2017; Fernandez-Arcaya et al., 2017; Näkki et al., 2017; Nelms et al., 2019). Microplastics may act as focal points for various toxins and hydrophobic compounds as demonstrated by Mato et al. (2001) who showed that PCB (polychlorinated biphenyls) concentration on polypropylene particles from offshore Japan was up to $10^{6}$ higher than the surrounding seawater. These toxins may be concentrated in benthic organisms which consume them (Taylor et al., 2016; Courtene-Jones et al., 2017). Submarine canyons act to concentrate macrophyte and terrestrial organic matter, as well as other nutrients including those of an anthropogenic origin (e.g., Khripounoff et al., 2003; Pham et al., 2014). Oxygen and nutrient enrichment in modern channel and canyon environments has an influence on the benthic fauna that can be sustained. As an example, oxygen levels in $\mathrm{La}$ Jolla Canyon (offshore California) at $500 \mathrm{~m}$ depth are highly variable, averaging $1.37 \mathrm{ml} / \mathrm{l}$ but due to tidal oscillations range between 0.5 and $2.1 \mathrm{ml} / \mathrm{l}$. In comparison, non-canyon areas at the same depth averaged $0.74 \mathrm{ml} / \mathrm{l}$ (Vetter and Dayton, 1998). Nutrient levels in the Congo fan are 100 times higher than the adjacent slope (Khripounoff et al., 2003). Seafloor sediment samples from Kaikoura Canyon, New Zealand, yielded an average of $>500$ individuals $\mathrm{m}^{-2}$ and a biomass of $\mathrm{c}$. $1,300 \mathrm{~g} \mathrm{~m}^{-2}$; adjacent slope environments yielded an average of $<50$ individuals $\mathrm{m}^{-2}$ and biomass of $<100 \mathrm{~g} \mathrm{~m}^{-2}$ (Rex et al., 2006; De Leo et al., 2010). Similar scenarios have been reported from other canyons globally (e.g., Cunha et al., 2011). Due to this enrichment, submarine channels and canyons can contain a greater faunal density and/or biomass than adjacent non-channel/canyon regions of the slope or basin floor (Griggs et al., 1969; Vetter and Dayton, 1998; Gerino et al., 1999; De Leo et al., 2010; Duffy et al., 2013; Pham et al., 2014). As canyons are most likely repositories for microplastics (at least over decadal timescales), their critical role in marine ecosystems is potentially at risk.

The depth to which organisms burrow is also greater in more active parts of submarine sedimentary systems, as organisms burrow to find buried nutrients in the thicker deposits of these environments, and perhaps to evade evacuation by turbidity currents (Young et al., 1985; Wetzel, 1991; Gerino et al., 1999). It has recently been shown that bioturbation may extend into the subsurface by up to $8 \mathrm{~m}$, which has implications for mixing of anthropogenic sediment with older sediment (Cobain et al., 2018). Many organisms have been shown to 
consume microplastic particle and fibers, including polychaetes, molluscs including bivalves and brachiopods, echinoderms and copepods (e.g., Thompson et al., 2004; Ward and Shumway, 2004; Graham and Thompson, 2009; Cole et al., 2013). These particles can translocate into the tissue of organisms or be recycled in fecal pellets (Browne et al., 2008; von Moos et al., 2012). Taylor et al. (2016) shows evidence of microplastic (fiber) ingestion in the deep sea - from the midAtlantic and SW Indian Ocean. Various organisms showed accumulation of fibers within their tissues and hard parts. For example, a hermit crab from approximately $1,050 \mathrm{~m}$ depth in the SW Indian Ocean was found to yield five microfibers (Taylor et al., 2016). This is important as microplastics can concentrate organic pollutants and absorb metals which can then be consumed by marine organisms (Taylor et al., 2016). In a recent study of larger marine mammals washed up on United Kingdom beaches, all were found to have ingested microplastics; however, the pathways for trophic transfer remain unclear (Nelms et al., 2019). Some of this consumption could be accidental (e.g., by filter feeding), but some is likely transferred upward from benthic organisms which have been shown to ingest microplastics (e.g., Thompson et al., 2004; Ward and Shumway, 2004; Graham and Thompson, 2009; Claessens et al., 2013; Cole et al., 2013; Farrell and Nelson, 2013). In the Rockall Trough, of the 66 invertebrates identified, $48 \%$ had ingested microplastics in quantities comparable to coastal species (Courtene-Jones et al., 2017). Whilst it is clear that microplastics are entering the food chain, it is unclear how the depositional environments of microplastic accumulation are distributed, and how these relate to ecosystem variability. Therefore there is a pressing need to better integrate studies that address particulate transport, deep-sea microplastic sequestration and the resultant ecological implications.

\section{SUMMARY AND CONCLUSION}

The study of microplastics in deep-marine environments is in its infancy. While it has been shown that microplastics occur within seafloor sediments, the necessary sedimentological data to make meaningful predictions of the seafloor distribution of microplastics, such as grain size and mineralogy of the host sediment, specific depositional environment or seafloor current regimes, are currently lacking. Datasets which constrain microplastic input from the terrestrial realm, capture information on microplastics fed to deep-marine canyons and over the shelf edge by other means, and which document distributions in specific seafloor depositional environments, are essential in the development of process-product models for microplastic distribution. Experimental and physical models of microplastic behavior in sediment gravity flows are a vital step toward understanding the behavior in natural systems. The longevity of plastics in deep, cold, settings is poorly understood and an area requiring further research. Developing a basic understanding of the seafloor processes that control and modulate the distribution of microplastics is essential as we begin to understand their effect on benthic organisms and their passage into the trophic chain. The implications of ingested microplastics on fishing stocks as well as directly for human health are as-yet poorly understood, hence, a concerted research effort is required on multiple fronts. We hope some of the suggestions herein will contribute to addressing this global environmental crisis to address these and other societal and economic implications.

\section{A Pressing Need to Understand the Processes by Which Microplastics Are Transported in the Deep-Sea}

Microplastics pervade the modern day seafloor across the full range of marine environments. These light and highly mobile particles are delivered to the coast by rivers, wind and ice and to the sea surface from shipping and marine industries. The relative abundance of microplastics in submarine canyons and deep-sea trenches suggests that delivery of microplastics to the seafloor is strongly controlled by gravity currents (although this remains to be proven), and by settling from the surface through the water column, aided by densification processes such as mineral accretion and biofouling. Microplastic fragments, in particular, show an affinity with areas where macroplastics and marine litter are common (e.g., submarine canyons), while microfibers have a wider distribution and are likely to be transported easily by bottom currents. The role of redistribution by bottom currents is not well understood but we suggest that microplastics can be easily distributed far from direct input points such as major rivers.

\section{Depositional and Post-depositional Processes Are Considered Strong Controls on the Ultimate Fate of Microplastics}

Microplastics may be buried much deeper than is currently assumed. Sediment accumulation rates differ vastly according to depositional environment; hence in certain settings, microplastic-bearing sediments may be tens of meters thick and sampling the top few $\mathrm{cm}$ is therefore not always representative. Sediment preservation potential will dictate the storage time of microplastics at specific points within a submarine depositional system. Canyon and channel axes are prone to flushing and reworking, while levees, other overbank areas, and distal lobes are sites of lower disturbance, and hence enhanced preservation potential. The depth of microplastic burial as well as the density of those accumulations both influence bioavailability. While trophic transfer of these microplastics is highly likely, burrowing organisms are likely to mix the microplastic interface to deeper levels and the implications for the wider food web remain unclear. What is clear is that sites with high microplastic input are often foci for diverse and dense benthic communities. This is because the same seafloor flows flows that transfer the oxygen and nutrients that sustain them are also capable of transporting microplastics. 


\section{Future Recommendations}

We have explained the important role different transport processes may play in the transport, accumulation density, and sequestration of microplastics in the deep-sea, yet few studies provide contextual information to enable detailed analysis nor to further develop predictive models. Future studies documenting microplastics on the seafloor should (at the very least) provide basic sedimentological information (grain size and mineralogy of the host sediment; depositional environment; water depth). These are all easily determined once a sample has been collected and should be provided alongside analytical information on microplastics (morphology, polymer type, size, shape, density, etc.). Better constraint on the sources (such as fluvial inputs) and the transfer route(s) of marine microplastics from shelf to deep sea is crucial in order to developed more robust global budgets for microplastics. Improved physical models to explain microplastic settling, and the behavior of fragments and fibers in thermohaline currents and gravity flows, will enable more effective microplastic transport models to be developed. These are required for global distribution models, to forecast future transport pathways, and potentially to inform mitigation strategies concerning their dispersal to critical offshore regions.

\section{REFERENCES}

Aller, R. C., and Blair, N. E. (2006). Carbon remineralization in the AmazonGuianas tropical mobile mudbelt: a sedimentary incinerator. Cont. Shelf Res. 26, 2241-2259.

Allin, J. R., Hunt, J. E., Talling, P. J., Clare, M. A., Pope, E., and Masson, D. G. (2016). Different frequencies and triggers of canyon filling and flushing events in Nazaré Canyon, offshore Portugal. Mar. Geol. 371, 89-105.

Alomar, C., Estarellas, F., and Deudero, S. (2016). Microplastics in the Mediterranean Sea: deposition in coastal shallow sediments, spatial variation and preferential grain size. Mar. Environ. Res. 115, 1-10. doi: 10.1016/j. marenvres.2016.01.005

Amy, L. A., Talling, P. J., Edmonds, V. O., Sumner, E. J., and Lesueur, A. (2006). An experimental investigation of sand- mud suspension settling behaviour: implications for bimodal mud contents of submarine flow deposits. Sedimentology 53, 1411-1434.

Andrady, A. L. (2011). Microplastics in the marine environment. Mar. Pollut. Bull. 62, 1596-1605. doi: 10.1016/j.marpolbul.2011.05.030

Andrady, A. L., and Neal, M. A. (2009). Applications and societal benefits of plastics. Philos. Trans. R. Soc. B Biol. Sci. 364, 1977-1984. doi: 10.1098/rstb.2008. 0304

Arthur, C., Baker, J. E., and Bamford, H. (eds) (2009). Proceedings of the International Research Workshop on the Occurrence, Effects and Fate of Microplastic Marine Debris, September 9-11, 2008. NOAA Technical Memorandum NOS-ORandR-30.

Ayranci, K., Lintern, D. G., Hill, P. R., and Dashtgard, S. E. (2012). Tide-supported gravity flows on the upper delta front, Fraser River delta, Canada. Mar. Geol. 326, 166-170.

Azpiroz-Zabala, M., Cartigny, M. J. B., Talling, P. J., Parsons, D. R., Sumner, E. J., Clare, M. A., et al. (2017). Newly recognized turbidity current structure can explain prolonged flushing of submarine canyons. Sci. Adv. 3:e1700200.

Baas, J. H., and Best, J. L. (2002). Turbulence modulation in clay-rich sedimentladen flows and some implications for sediment deposition. J. Sediment. Res. 72, 336-340.

Babonneau, N., Savoye, B., Cremer, M., and Klein, B. (2002). Morphology and architecture of the present canyon and channel system of the Zaire deep-sea fan. Mar. Pet. Geol. 19, 445-467.

\section{AUTHOR CONTRIBUTIONS}

IK led on the review but both authors contributed equally to the writing and figure preparation.

\section{FUNDING}

MC was supported by the NERC National Capability CLASS Programme [Climate Linked Atlantic Sector Science Programme (No. NE/R015953/1)].

\section{ACKNOWLEDGMENTS}

This work was conducted as part of a joint Manchester University-NOC project - SCaMpI (Seafloor Currents and Micro-Plastics Investigation). We acknowledge the constructive reviews of the reviewers, $\mathrm{RB}$ and $\mathrm{AG}$, and the useful summary and review by the editor $\mathrm{DH}$. We also thank Thomas Bishop and John Moore (School of Geography, University of Manchester) for technical assistance with extraction of microplastics shown in Figure 1.

Baker, M. L., Baas, J. H., Malarkey, J., Silva, R., Craig, M. J., Kane, I. A., et al. (2017). The effect of clay type on the properties of cohesive sediment gravity flows and their deposits. J. Sediment. Res. 87, 1176-1195. doi: 10.2110/jsr. 2017.63

Ballent, A., Pando, S., Purser, A., Juliano, M. F., and Thomsen, L. (2013). Modelled transport of benthic marine microplastic pollution in Nazare Canyon. Biogeosciences 10, 7957-7970.

Barboza, L. G. A., Vethaak, A. D., Lavorante, B. R., Lundebye, A. K., and Guilhermino, L. (2018). Marine microplastic debris: an emerging issue for food security, food safety and human health. Mar. Pollut. Bull. 133, 336-348. doi: 10.1016/j.marpolbul.2018.05.047

Barnes, D. K. A., Galgani, F., Thompson, R. C., and Barlaz, M. (2009). Accumulation and fragmentation of plastic debris in global environments. Philos. Trans. R. Soc. Lond. B Biol. Sci. 364, 1985-1998. doi: 10.1098/rstb.2008. 0205

Belcher, A., Henson, S. A., Manno, C., Hill, S. L., Atkinson, A., Thorpe, S. E., et al. (2019). Krill faecal pellets drive hidden pulses of particulate organic carbon in the marginal ice zone. Nat. Commun. 10:889. doi: 10.1038/s41467-019-08847-1

Bergmann, M., and Klages, M. (2012). Increase of litter at the Arctic deep-sea observatory HAUSGARTEN. Mar. Pollut. Bull. 64, 2734-2741. doi: 10.1016/j. marpolbul.2012.09.018

Bergmann, M., Wirzberger, V., Krumpen, T., Lorenz, C., Primpke, S., Tekman, M. B., et al. (2017). High Quantities of Microplastic in Arctic Deep-Sea Sediments from the HAUSGARTEN Observatory. Environ. Sci. Technol. 51, 11000-11010. doi: 10.1021/acs.est.7b03331

Biscara, L., Hanquiez, V., Leynaud, D., Marieu, V., Mulder, T., Gallissaires, J. M., et al. (2012). Submarine slide initiation and evolution offshore Pointe Odden, Gabon-Analysis from annual bathymetric data (2004-2009). Mar. Geol. 299, 43-50.

Blum, M., Rogers, K., Gleason, J., Najman, Y., Cruz, J., and Fox, L. (2018). Allogenic and autogenic singlans in the stratigraphic record of the deep-se Bengal Fan. Sci. Rep. 8:7973. doi: 10.1038/s41598-018-25819-5

Bouma, A. H. (1962). Sedimentology of Some Flysch Deposits: A Graphic Approach to Facies Interpretation. Amsterdam: Elsevier, 168.

Booth, J. S., O’Leary, D. W., Popenoe, P., and Danforth, W. W., (1993). "U.S. Atlantic continental slope landslides: their distribution, general attributes, and implications," in Submarine landslides: Selected studies in the U.S. Exclusive 
Economic Zone: U.S. Geological Survey Bulletin no. 2002, eds W. C. Schwab, H. J. Lee, D. C. Twichell (Denver, CO: U.S Department of interior), 14-22.

Browne, M. A., Crump, P., Niven, S. J., Teuten, E., Tonkin, A., Galloway, T., et al. (2011). Accumulation of microplastic on shorelines woldwide: sources and sinks. Environ. Sci. Technol. 45, 9175-9179. doi: 10.1021/es201811s

Browne, M. A., Dissanayake, A., Galloway, T. S., Lowe, D. M., and Thompson, R. C. (2008). Ingested microscopic plastic translocates to the circulatory system of the mussel, Mytilus edulis (L.). Environ. Sci. Technol. 42, 5026-5031.

Browne, M. A., Galloway, T. S., and Thompson, R. C. (2010). Spatial patterns of plastic debris along estuarine shorelines. Environ. Sci. Technol. 44, 3404-3409. doi: $10.1021 /$ es903784e

Buchanan, J. B. (1971). Pollution by synthetic fibres. Mar. Pollut. Bull. 2:23.

Buhl-Mortensen, L., and Buhl-Mortensen, P. (2017). Marine litter in the Nordic Seas: distribution composition and abundance. Mar. Pollut. Bull. 125, 260-270. doi: 10.1016/j.marpolbul.2017.08.048

Carpenter, E. J., Anderson, S. J., Harvey, G. R., Miklas, H. P., and Peck, B. B. (1972). Polystyrene spherules in coastal waters. Science 178, 749-750.

Carpenter, E. J., and Smith, K. L. (1972). Plastics on the Sargasso sea surface. Science 175, 1240-1241.

Carter, L., Milliman, J. D., Talling, P. J., Gavey, R., and Wynn, R. B. (2012). Nearsynchronous and delayed initiation of long run-out submarine sediment flows from a record-breaking river flood, offshore Taiwan. Geophys. Res. Lett. 39:12.

Chiba, S., Saitoc, H., Fletcher, R., Yogid, T., Kayod, M., Miyagid, S., et al. (2018). Human footprint in the abyss: 30 year records of deep-sea plastic debris. Mar. Policy 96, 204-212.

Chubarenko, I., Bagaiev, A., Zobkov, M., and Esiukova, E. (2016). On some physical and dynamical properties of microplastic particles in marine environment. Mar. Pollut. Bull. 108, 105-112. doi: 10.1016/j.marpolbul.2016.04.048

Chubarenko, I. P., Esiukova, E. E., Bagaev, A. V., and Grave, A. N. (2018). Threedimensional distribution of anthropogenic microparticles in the body of sandy beaches. Sci. Total Environ. 628, 1340-1351.

Claessens, M., De Meester, S., Van Landuyt, L., De Clerck, K., and Janssen, C. R. (2011). Occurrence and distribution of microplastics in marine sediments along the Belgian coast. Mar. Pollut. Bull. 62, 2199-2204. doi: 10.1016/j.marpolbul. 2011.06.030

Claessens, M., Van Cauwenberghe, L., Vandegehuchte, M. B., and Janssen, C. R. (2013). New techniques for the detection of microplastics in sediments and field collected organisms. Mar. Pollut. Bull. 70, 227-233. doi: 10.1016/j.marpolbul. 2013.03.009

Clare, M. A., Hughes Clarke, J. E., Talling, P. J., Cartigny, M. J., and Pratomo, D. G. (2016). Preconditioning and triggering of offshore slope failures and turbidity currents revealed by most detailed monitoring yet at a fjord-head delta. Earth Planet. Sci. Lett. 450, 208-220.

Clare, M. A., Talling, P. J., Challenor, P., Malgesini, G., and Hunt, J. (2014). Distal turbidites reveal a common distribution for large $(0.1 \mathrm{~km} 3)$ submarine landslide recurrence. Geology 42, 263-266.

Clare, M. A., Vardy, M. E., Cartigny, M. J., Talling, P. J., Himsworth, M. D., Dix, J. K., et al. (2017). Direct monitoring of active geohazards: emerging geophysical tools for deep-water assessments. Near Surf. Geophys. 15, 427-444.

Clark, J. D., and Pickering, K. T. (1996). Architectural elements and growth patterns of submarine channels: application to hydrocarbon exploration. AAPG Bull. 80, 194-220.

Cobain, S. L., Hodgson, D. M., Peakall, J., Wignall, P. B., and Cobain, M. R. D. (2018). A new macrofaunal limit in the deep biosphere revealed by extreme burrow depths in ancient sediments. Sci. Rep. 8:261. doi: 10.1038/s41598-01718481-w

Cole, M., Lindeque, P., Fileman, E., Halsband, C., Goodhead, R., Moger, J., et al. (2013). 'Microplastic Ingestion by Zooplankton'. Environ. Sci. Technol. 47, 6646-6655. doi: 10.1021/es400663f

Cole, M., Lindeque, P., Halsband, C., and Galloway, T. S. (2011). Microplastics as contaminants in the marine environment: a review. Mar. Pollut. Bull. 62, 2588-2597. doi: 10.1016/j.marpolbul.2011.09.025

Cole, M., Lindeque, P. K., Fileman, E., Clark, J., Lewis, C., Halsband, C., et al. (2016). Microplastics alter the properties and sinking rates of zooplankton faecal pellets. Environ. Sci. Technol. 50, 3239-3246. doi: 10.1021/acs.est. 5 b05905

Colton, J. B. Jr., Knapp, F. D., and Burns, B. R. (1974). Plastic particles in surface waters of the northwestern Atlantic. Science 185, 491-497.
Corcoran, P. L., Jazvac, K., and Ballent, A. (2017). "Plastics and the anthropocene," in Encyclopedia of the Anthropocene, Vol. 2, eds D. A. DellaSala and M. I. Goldstein (Amsterdam: Elsevier).

Corcoran, P. L., Norris, T., Ceccanese, T., Walzak, M. J., Helm, P. A., and Marvin, C. H. (2015). Hidden plastics of Lake Ontario: Canada and their potential preservation in the sediment record. Environ. Pollut. 204, 17-25. doi: 10.1016/ j.envpol.2015.04.009

Cosgrove, G. I. E., Hodgson, D. M., Poyatos-Moré, M., Mountney, N. P., and McCaffrey, W. D. (2018). Filter or conveyor? Establishing relationships between clinoform rollover trajectory, sedimentary process regime, and grain character within intrashelf clinothems, offshore New Jersey, U.S.A. J. Sediment. Res. 88, 917-941. doi: 10.2110/jsr.2018.44

Costa, M. F., and Barletta, M. (2015). Microplastics in coastal and marine environments of the western tropical and sub-tropical Atlantic Ocean Environ. Sci. Process. Impacts 17, 1868-1879. doi: 10.1039/c5em00158g

Courtene-Jones, W., Quinn, B., Gary, S. F., Mogg, A. O., and Narayanaswamy, B. E. (2017). Microplastic pollution identified in deep-sea water and ingested by benthic invertebrates in the Rockall Trough, North Atlantic Ocean. Environ. Pollut. 231, 271-280. doi: 10.1016/j.envpol.2017.08.026

Covault, J. A., Normark, W. R., Romans, B. W., and Graham, S. A. (2007). Highstand fans in the California borderland: the overlooked deep-water depositional systems. Geology 35, 783-786.

Cózar, A., Echevarria, F., Gonzalez-Gordillo, J. I., Irigoien, X., Úbeda, B., Hernandez-Leon, S., et al. (2014). Plastic debris in the open ocean. Proc. Natl. Acad. Sci. U.S.A. 111, 10239-10244. doi: 10.1073/pnas.1314705111

Cunha, M. R., Paterson, G. L., Amaro, T., Blackbird, S., de Stigter, H. C., Ferreira, C., et al. (2011). Biodiversity of macrofaunal assemblages from three Portuguese submarine canyons (NE Atlantic). Deep Sea Res. Part 2 Top. Stud. Oceanogr. 58, 2433-2447.

Davies, J. R., Fletcher, C. J. N., Waters, R. A., and Wilson, D. (1997). Geology of the Country Around Llanilar and Rhayader. Memoir of the British Geological Survey, Sheets 178 \& 179. London: The Stationery Office.

De Leo, F. C., Smith, C. R., Rowden, A. A., Bowden, D. A., and Clark, M. R. (2010). Submarine canyons: hotspots of benthic biomass and productivity in the deep sea. Proc. R. Soc. B Biol. Sci. 277, 2783-2792. doi: 10.1098/rspb.2010.0462

Dekiff, J. H., Remy, D., Klasmeier, J., and Fries, E. (2014). Occurrence and spatial distribution of microplastics in sediments from Norderney. Environ. Pollut. 186, 248-256. doi: 10.1016/j.envpol.2013.11.019

Deptuck, M. E., Piper, D. J. W., Savoye, B., and Gervais, A. (2008). Dimensions and architecture of late Pleistocene submarine lobes off the northern margin of East Corsica. Sedimentology 55, 869-898.

Dietrich, W. E. (1982). Settling velocity of natural particles. Water Resour. Res. 18, $1615-1626$.

Doyle, M. J., Watson, W., Bowlin, N. M., and Sheavly, S. B. (2011). Plastic particles in coastal pelagic ecosystems of the Northeast Pacific ocean. Mar. Environ. Res. 71, 41-52. doi: 10.1016/j.marenvres.2010.10.001

Dubaish, F., and Liebezeit, G. (2013). Suspended microplastics and black carbon particles in the Jade system, southern North Sea. Water Air Soil Pollut. 224:1352.

Duffy, G. A., Lundsten, L., Kuhnz, L. A., and Paull, C. K. (2013). A comparison of megafaunal communities in five submarine canyons off southern California, USA. Deep-Sea Res. 2 Top. Stud. Oceanogr. 104, 259-266. doi: 10.1016/j.dsr2. 2013.06.002

Eidam, E. F., Ogston, A. S., and Nittrouer, C. A. (2019). Formation and removal of a coastal flood deposit. J. Geophys. Res. Oceans 124, 1045-1062.

Eriksen, M., Lebreton, L. C. M., Carson, H. S., Thief, M., Moore, C. J., Borerro, J. C., et al. (2014). Plastic pollution in the world's oceans: more than 5 trillion plastic pieces weighing over 250,000 tons afloat at Sea. PLoS One 9:e111913. doi: 10.1371/journal.pone.0111913

Farrell, P., and Nelson, K. (2013). Trophic level transfer of microplastic: Mytilus edulis (L.) to Carcinus maenas (L.). Environ. Pollut. 177, 1-3. doi: 10.1016/j. envpol.2013.01.046

Faugères, J.-C., Mézerais, M. L., and Stow, D. A. V. (1993). Contourite drift types and their distribution in the North and South Atlantic Ocean basins. Sediment. Geol. 82, 189-203.

Fazey, F. M., and Ryan, P. G. (2016). Biofouling on buoyant marine plastics: an experimental study into the effect of size on surface longevity. Environ Pollut. 210, 354-360. doi: 10.1016/j.envpol.2016.01.026 
Fendall, L. S., and Sewell, M. A. (2009). Contributing to marine pollution by washing your face: microplastics in facial cleansers. Mar. Pollut. Bull. 58, 1225-1228. doi: 10.1016/j.marpolbul.2009.04.025

Ferguson, R. I., and Church, M. (2004). A simple universal equation for grain settling velocity. J. Sediment. Res. 74, 933-937. doi: 10.1306/051204740933

Fernandez-Arcaya, U., Ramirez-Llodra, E., Aguzzi, J., Allcock, A. L., Davies, J. S., Dissanayake, A., et al. (2017). Ecological role of submarine canyons and need for canyon conservation: a review. Front. Mar. Sci. 4:5. doi: 10.3389/fmars.2017. 00005

Fildani, A. (2017). Submarine canyons: a brief review looking forward. Geology 45, 383-384.

Fildani, A., Clark, J., Covault, J. A., Power, B., Romans, B. W., and Aiello, I. W. (2018). Muddy sand and sandy mud on the distal Mississippi fan: Implications for lobe depositional processes. Geosphere 14, 1051-1066. doi: 10.1130/GES01580.1

Fischer, V., Elsner, N. O., Brenke, N., Schwabe, E., and Brandt, A. (2015). Plastic pollution of the Kuril-Kamchatka Trench area (NW pacific). Deep Sea Res. Part 2 Top. Stud. Oceanogr. 111, 399-405. doi: 10.1016/j.dsr2.2014.08.012

Gales, J. A., Talling, P. J., Cartigny, M. J., Hughes Clarke, J., Lintern, G., Stacey, C., et al. (2018). What controls submarine channel development and the morphology of deltas entering deep-water fjords? Earth Surf. Process. Landf. $44,535-551$.

Galgani, F., Hanke, G., and Maes, T. (2015). "Global distribution, composition and abundance of marine litter," in Marine Anthropogenic Litter, eds M. Bergmann, L. Gutow, and M. Klages (Cham: Springer), 29-56.

Gall, S. C., and Thompson, R. C. (2015). The impact of debris on marine life. Mar. Pollut. Bull. 92, 170-179. doi: 10.1016/j.marpolbul.2014.12.041

Galloway, T. S. (2015). "Micro-and nano-plastics and human health," in Marine Anthropogenic Litter, eds M. Bergmann, L. Gutow, and M. Klages (Cham: Springer), 343-366.

Galloway, W. E., Whiteaker, T. L., and Ganey-Curry, P. E. (2013). History of Cenozoic North American drainage basin evolution, sediment yield, and accumulation in the Gulf of Mexico basin. Geosphere 7, 938-973. doi: 10.1130/ GES00647.1

Galy, V., France-Lanord, C., Beyssac, O., Faure, P., Kudrass, H., and Palhol, F. (2007). Efficient organic carbon burial in the Bengal fan sustained by the Himalayan erosional system. Nature 450:407.

Gerino, M., Stora, G., and Weber, O. (1999). Evidence of bioturbation in the CapFerret Canyon in the deep northeastern Atlantic. Deep Sea Res. Part 2 Top. Stud. Oceanogr. 46, 2289-2307.

Gervais, A., Savoye, B., Mulder, T., and Gonthier, E. (2006). Sandy modern turbidite lobes: a new insight from high resolution seismic data. Mar. Petrol. Geol 23, 485-502.

GESAMP (2016). "Sources, fate and effects of microplastics in the marine environment: part two of a global assessment," in (IMO/FAO/ UNESCOIOC/UNIDO/WMO/IAEA/UN/UNEP/UNDP Joint Group of Experts on the Scientific Aspects of Marine Environmental Protection), (GESAMP Reports \& Studies No 93, eds P. J. Kershaw and C. M. Rochman (London: GESAMP).

Geyer, R., Jambeck, J. R., and Law, K. L. (2017). Production, use, and fate of all plastics ever made. Sci. Adv. 3:e1700782. doi: 10.1126/sciadv.1700782

Goldberg, E. D. (1997). Plasticizing the seafloor: an overview. Environ. Technol. 18, 195-201.

Graca, B., Szewc, K., Zakrzewska, D., Dołęga, A., and Szczerbowska-Boruchowska, M. (2017). Sources and fate of microplastics in marine and beach sediments of the Southern Baltic Sea-a preliminary study. Environ Sci Pollut Res. 24, 7650-7661. doi: 10.1007/s11356-017-8419-5

Graham, E. R., and Thompson, J. T. (2009). Deposit- and suspension-feeding sea cucumbers (Echinodermata) ingest plastic fragments. J. Exp. Mar. Biol. Ecol. $368,22-29$.

Gregory, M. R. (1978). Accumulation and distribution of virgin plastic granules on New Zealand beaches. N. Z. J. Mar. Freshw. Res. 12, 399-414.

Gregory, M. R. (2009). Environmental implications of plastic debris in marine settings-entanglement, ingestion, smothering, hangers-on, hitch-hiking and alien invasions. Philos. Trans. R. Soc. B Biol. Sci. 364, 2013-2025. doi: 10.1098/ rstb.2008.0265

Griggs, G. B., Carey, A. G. Jr., and Kulm, L. D. (1969). Deep-sea sedimentation and sediment-fauna interaction in Cascadia Channel and on Cascadia Abyssal Plain. Deep Sea Res. Oceanogr. Abstr. 16, 157-170.
Gwiazda, R., Paull, C. K., Ussler, W. III, and Alexander, C. R. (2015). Evidence of modern fine-grained sediment accumulation in the Monterey Fan from measurements of the pesticide DDT and its metabolites. Mar. Geol. 363, $125-133$.

Hage, S., Cartigny, M. J., Clare, M. A., Sumner, E. J., Vendettuoli, D., Hughes Clarke, J. E., et al. (2018). How to recognize crescentic bedforms formed by supercritical turbidity currents in the geologic record: Insights from active submarine channels. Geology 46, 563-566.

Hansen, L., Janocko, M., Kane, I. A., and Kneller, B. C. (2017). Submarine channel evolution, terrace development, and preservation of intra-channel thin-bedded turbidites: Mahin and Avon channels, offshore Nigeria. Mar. Geol. 383, 146167. doi: 10.1016/j.margeo.2016.11.011

Hansen, L. A., Callow, R. H., Kane, I. A., Gamberi, F., Rovere, M., Cronin, B. T., et al. (2015). Genesis and character of thin-bedded turbidites associated with submarine channels. Mar. Pet. Geol. 67, 852-879.

Hardesty, B. D., Harari, J., Isobe, A., Lebreton, L., Maximenko, N., Potemra, J., et al. (2017). Using Numerical Model Simulations to Improve the Understanding of Micro-plastic Distribution and Pathways in the Marine Environment. Front. Mar. Sci. 4:30. doi: 10.3389/fmars.2017.00030

Haughton, P. D. W., Barker, S. P., and McCaffrey, W. D. (2003). 'Linked' debrites in sand-rich turbidite systems - origin and significance. Sedimentology 50 , 459-482.

Hiscott, R. N. (1994). Loss of capacity, not competence, as the fundamental process governing deposition from turbidity currents. J. Sediment. Res. 64, 209-214.

Hizzett, J. L., Hughes Clarke, J. E., Sumner, E. J., Cartigny, M. J. B., Talling, P. J., and Clare, M. A. (2018). Which triggers produce the most erosive, frequent, and longest runout turbidity currents on deltas? Geophys. Res. Lett. 45, 855-863.

Hodgson, D. M. (2009). Distribution and origin of hybrid beds in sand-rich submarine fans of the Tanqua depocentre, Karoo Basin, South Africa. Mar. Pet. Geol. 26, 1940-1956.

Hodgson, D. M., Browning, J. V., Miller, K. G., Hesselbo, S. P., Poyatos-Moré, M., Mountain, G. S., et al. (2018a). Sedimentology, stratigraphic context, and implications of Miocene intrashelf bottomset deposits, offshore New Jersey. Geosphere 141, 95-114.

Hodgson, D. M., Bernhardt, A., Clare, M., Silva, A., Fosdick, J., Mauz, B., et al. (2018b). Grand Challenges (and Great Opportunities) in Sedimentology, Stratigraphy, and Diagenesis Research. Front. Earth Sci. 6:173. doi: 10.3389/ feart.2018.00173

Hodgson, D. M., Flint, S. S., Hodgetts, D., Drinkwater, N. J., Johannessen, E. P., and Luthi, S. M. (2006). Stratigraphic evolution of fine-grained submarine fan systems, Tanqua depocenter, Karoo Basin, South Africa. J. Sediment. Res. 76, 20-40. doi: $10.2110 /$ jsr.2006.03

Högberg, S. M., Åkerstedt, H. O., Lundström, T. S., and Freund, J. B. (2010). Respiratory deposition of fibers in the non-inertial regime-development and application of a semi-analytical model. Aerosol Sci. Technol. 44, 847-860. doi: $10.1080 / 02786826.2010 .498455$

Horton, A. A., and Dixon, S. J. (2017). Microplastics: an introduction to environmental transport processes. WIREs Water 2018:e1268. doi: 10.1002/ wat2.1268

Horton, A. A., Svendsen, C., Williams, R. J., Spurgeon, D. J., and Lahive, E. (2017). Large microplastic particles in sediments of tributaries of the River Thames, UK-abundance, sources and methods for effective quantification. Mar. Pollut. Bull. 114, 218-226. doi: 10.1016/j.marpolbul.2016.09.004

Hunt, J. E. (2017). Identifying and quantifying erosion beneath the deposits of long-runout turbidity currents along their pathway. Mar. Geol. 389, 32-51.

Hurley, R., Woodward, J., and Rothwell, J. R. (2018). Microplastic contamination of river beds significantly reduced by catchment-wide flooding. Nat. Geosci. 11, 251-257.

Ilstad, T., Elverhøi, A., Issler, D., and Marr, J. G. (2004). Subaqueous debris flow behaviour and its dependence on the sand/clay ratio: a laboratory study using particle tracking. Mar. Geol. 213, 415-438.

Inman, D. L., Nordstrom, C. E., and Flick, R. E. (1976). Currents in submarine canyons: an air-sea-land interaction. Annu. Rev. Fluid Mech. 8, 275-310.

Ivar do Sul, J. A., and Costa, M. F. (2007). Marine debris review for Latin America and the wider Caribbean region: from the 1970s until now, and where do we go from here? Mar. Pollut. Bull. 54, 1087-1104. doi: 10.1016/j.marpolbul.2007. 05.004 
Jambeck, J. R., Geyer, R., Wilcox, C., Siegler, T. R., Perryman, M., Andrady, A., et al. (2015). Plastic waste inputs from land into the ocean. Science 347, 768-771. doi: 10.1126/science. 1260352

Jegou, I., Savoye, B., Pirmez, C., and Droz, L. (2008). Channel-mouth lobe complex of the recent Amazon Fan: the missing piece. Mar. Geol. 252, 62-77.

Jobe, Z., Sylvester, N., Parker, A. O., Howes, N., Slowey, N., and Pirmez, C. (2015). Rapid adjustment of submarine channel architecture to changes in sediment supply. J. Sediment. Res. 85, 729-753.

Johnson, S. D., Flint, S., Hinds, D., and Wickens, H. D. V. (2001). Anatomy, geometry and sequence stratigraphy of basin floor to slope turbidite systems, Tanqua Karoo, South Africa. Sedimentology 48, 987-1023.

Kaiser, D., Kowlaski, N., and Waniek, J. J. (2017). Effects of biofouling on the sinking behavior of microplastics. Environ. Res. Lett. 12:124003. doi: 10.1016/ j.envpol.2018.07.131

Kane, I., and Hodgson, D. (2011). Sedimentological criteria to differentiate submarine channel levee sub-environments: exhumed examples from the Rosario Fm. (Upper Cretaceous) of Baja California, Mexico, and the Fort Brown Fm. (Permian), Karoo Basin. S. Africa. Mar. Pet. Geol. 28, 807-823.

Kane, I., Kneller, B., Dykstra, M., Kassem, A., and McCaffrey, W. D. (2007). Anatomy of a submarine channel-levee: an example from Upper Cretaceous slope sediments, Rosario Formation, Baja California, Mexico. Mar. Pet. Geol. 24, 540-563. doi: 10.1016/j.marpetgeo.2007.01.003

Kane, I. A., and Pontén, A. S. M. (2012). Submarine transitional flow deposits in the Paleogene Gulf of Mexico. Geology 40, 1119-1122.

Kane, I. A., Pontén, A. S. M., Vangdal, B., Eggenhuisen, J. T., Hodgson, D. M., and Spychala, Y. T. (2017). The stratigraphic record and processes of turbidity current transformation across deep-marine lobes. Sedimentology 64, 12361273. doi: $10.1111 /$ sed.12346

Kanhai, L. D. K., Johansson, C., Frias, J. P. G. L., Gardfeldt, K., Thompson, R. C., and O'Connor, I. (2019). Deep sea sediments of the Arctic Central Basin: a potential sink for microplastics. Deep Sea Res. Part I Oceanogr. Res. Pap. 145, 137-142. doi: 10.1016/j.dsr.2019.03.003

Khatmullina, L., and Isachenko, I. (2017). Settling velocity of microplastic particles of irregular shapes. Mar. Pollut. Bull. 114, 871-880. doi: 10.1016/j.marpolbul. 2016.11.024

Khripounoff, A., Vangriesheim, A., Babonneau, N., Crassous, P., Dennielou, B., and Savoye, B. (2003). Direct observation of intense turbidity current activity in the Zaire submarine valley at $4000 \mathrm{~m}$ water depth. Mar. Geol. 194, 151-158.

Khripounoff, A., Vangriesheim, A., Crassous, P., and Etoubleau, J. (2009). High frequency of sediment gravity flow events in the Var submarine canyon (Mediterranean Sea). Mar. Geol. 263, 1-6.

Kineke, G. C., Woolfe, K. J., Kuehl, S. A., Milliman, J. D., Dellapenna, T. M., and Purdon, R. G. (2000). Sediment export from the Sepik River, Papua New Guinea: evidence for a divergent sediment plume. Cont. Shelf Res. 20, 2239-2266.

Kioka, A., Schwestermann, T., Moernaut, J., Ikehara, K., Kanamatsu, T., McHugh, C. M., et al. (2019). Megathrust earthquake drives drastic organic carbon supply to the hadal trench. Sci. Rep. 9:1553. doi: 10.1038/s41598-019-38834-x

Klein, S., Worch, E., and Knepper, T. P. (2015). Occurrence and spatial distribution of microplastics in river shore sediments of the Rhine-Main area in Germany. Environ. Sci. Technol. 49, 6070-6076.

Kneller, B. C. (1995). "Beyond the turbidite paradigm; physical models for deposition of turbidites and their implications for reservoir prediction," in Characterization of Deep Marine Clastic Systems. Geological Society, eds A. Hartley and J. Prosser (London: Special Publications), 31-49.

Kneller, B. C., and Branney, M. J. (1995). Sustained high-density turbidity currents and the deposition of thick massive sands. Sedimentology 42, 607-616.

Kowalski, N., Reichardt, A. M., and Waniek, J. J. (2016). Sinking rates of microplastics and potential implications of their alteration by physical, biological, and chemical factors. Mar. Pollut. Bull. 109, 310-319. doi: 10.1016/j. marpolbul.2016.05.064

Kuo, M., and Bolton, M. (2013). The nature and origin of deep ocean clay crust from the Gulf of Guinea. Géotechnique 63, 500-509.

Lebreton, L. C., Van der Zwet, J., Damsteeg, J. W., Slat, B., Andrady, A., and Reisser, J. (2017). River plastic emissions to the world's oceans. Nat. Commun. 8:15611. doi: $10.1038 /$ ncomms15611
Lee, I.-H., Lien, R.-C., Liu, J. T., and Chuang, W. S. (2009). Turbulent mixing and internal tides in Gaoping (Kaoping) Submarine Canyon, Taiwan. J. Mar. Syst. 76, 383-396.

Leslie, H. A., Brandsma, S. H., van Velzena, M. J. M., and Vethaak, A. D. (2017). Microplastics en route: Field measurements in the Dutch river delta and Amsterdam canals, wastewater treatment plants, North Sea sediments and biota. Environ. Int. 101, 133-142. doi: 10.1016/j.envint.2017.01.018

Li, P., Kneller, B. C., Hansen, L., and Kane, I. A. (2016). The classical turbidite outcrop at San Clemente, California, revisited: an example of sandy submarine channels with asymmetric facies architecture. Sediment. Geol. 346, 1-16.

Li, W. C., Tse, H. F., and Fok, L. (2016). Plastic waste in the marine environment: a review of sources, occurrence and effects. Sci. Total Environ. 566-567, 333-349. doi: 10.1016/j.scitotenv.2016.05.084

Lobelle, D., and Cunliffe, M. (2011). Early microbial biofilm formation on marine plastic debris. Mar. Pollut. Bull. 62, 197-200. doi: 10.1016/j.marpolbul.2010. 10.013

Long, M., Moriceau, B., Gallinari, M., Lambert, C., Huvet, A., Raffray, J., et al. (2015). Interactions between microplastics and phytoplankton aggregates: impact on their respective fates. Mar. Chem. 175, 39-46.

Lowe, D. R. (1982). Sediment gravity flows: II. Depositional models with special reference to the deposits of high- density turbidity currents. J. Sediment. Petrol. 52, 279-297.

Lusher, A. L. (2015). "Microplastics in the marine environment: distribution, interactions and effects," in Marine Anthropogenic Litter, eds M. Bergmann, L. Gutow, and M. Klages (Berlin: Springer), 245-307.

Maes, T., Barry, J., Leslie, H. A., Vethaak, A. D., Nicolaus, E. E. M., Law, R. J., et al. (2018). Below the surface: Twenty-five years of seafloor litter monitoring in coastal seas of North West Europe (1992-2017). Sci. Total Environ. 630, 790-798. doi: 10.1016/j.scitotenv.2018.02.245

Maes, T., Van der Meulen, M. D., Devriese, L. I., Leslie, H. A., Huvet, A., Frère, L., et al. (2017). Microplastics baseline surveys at the water surface and in sediments of the North-East Atlantic. Front. Mar. Sci. 4:135. doi: 10.3389/fmars. 2017.00135

Mani, T., Hauk, A., Walter, U., and Burkhardt-Holm, P. (2015). Microplastics profile along the Rhine River. Sci. Rep. 5:17988. doi: 10.1038/srep17988

Martin, J., Lusher, A., Thompson, R. C., and Morley, A. (2017). The deposition and accumulation of microplastics in marine sediments and bottom water from the Irish continental shelf. Nat. Sci. Rep. 7:10772. doi: 10.1038/s41598-017-11079-2

Mason, S. A., Garneau, D., Sutton, R., Chu, Y., Ehmann, K., Barnes, J., et al. (2016). Microplastic pollution is widely detected in US municipal wastewater treatment plant effluent. Environ. Pollut. 218, 1045-1054. doi: 10.1016/j.envpol.2016. 08.056

Masson, D. G., Harbitz, C. B., Wynn, R. B., Pedersen, G., and Løvholt, F. (2006). Submarine landslides: processes, triggers and hazard prediction. Philos. Trans. R. Soc. Lond. 364, 2009-2039.

Masson, D. G., Wynn, R. B., and Talling, P. J. (2010). "Large landslides on passive continental margins: processes, hypotheses and outstanding questions," in Submarine Mass Movements and their Consequences, eds D. C. Mosher, R. C. Shipp, L. Moscardelli, J. D. Chaytor, C. D. P. Baxter, H. J. Lee et al. (Dordrecht: Springer), 153-165.

Mato, Y., Isobe, T., Takada, H., Kanehiro, H., Ohtake, C., and Kaminuma, T. (2001). Plastic resin pellets as a transport medium for toxic chemicals in the marine environment. Environ. Sci. Technol. 35, 318-324.

McArthur, A. D., Gamberi, F., Kneller, B. C., Wakefield, M. I., Souza, P. A., and Kuchle, J. (2017). Palynofacies classification of submarine fan depositional environments: outcrop examples from the Marnoso-Arenacea Formation, Italy. Mar. Pet. Geol. 88, 181-199.

McCave, I. N., Thornalley, D. J. R., and Hall, I. R. (2017). Relation of sortable silt grain-size to deep-sea current speeds: Calibration of the 'Mud Current Meter'. Deep Sea Res. Part 1 Oceanogr. Res. Pap. 127, 1-12.

McNown, J. S., and Malaika, J. (1950). Effects of particle shape on settling velocity at low Reynolds numbers. Eos Trans. Am. Geophys. Union 31, 74-82.

Miramontes, E., Garreau, P., Caillaud, M., Jouet, G., Hernandez-Molina, J., Clare, M., et al. (2019). Contourite distribution and bottom currents in the NW Mediterranean Sea: coupling seafloor geomorphology and hydrodynamic modelling. Geomorphology

Mohrig, D. G., Whipple, K., Ellis, C., and Parker, G. (1998). Hydroplaning of subaqueous debris flows. Geol. Soc. Am. Bull. 110, 387-394. 
Moore, C. J., Lattin, G. L., and Zellers, A. F. (2011). Quantity and type of plastic debris flowing from two urban rivers to coastal waters and beaches of Southern California. J. Integr. Coast. Zone Manag. 11, 65-73.

Mordecai, G., Tyler, P. A., Masson, D. G., and Huvenne, V. A. I. (2011). Litter in submarine canyons off the west coast of Portugal. Deep Sea Res. Part 2 Top. Stud. Oceanogr. 58, 2489-2496. doi: 10.1016/j.dsr2.2011. 08.009

Moreira, F. T., Balthazar-Silva, D., Barbosa, L., and Turra, A. (2016). Revealing accumulation zones of plastic pellets in sandy beaches. Environ. Pollut. 218, 313-321. doi: 10.1016/j.envpol.2016.07.006

Morét-Ferguson, S., Law, K. L., Proskurowski, G., Murphy, E. K., Peacock, E. E., and Reddy, C. M. (2010). The size, mass, and composition of plastic debris in the western North Atlantic Ocean. Mar. Poll. Bull. 60, 1873-1878. doi: 10.1016/ j.marpolbul.2010.07.020

Mountjoy, J. J., Howarth, J. D., Orpin, A. R., Barnes, P. M., Bowden, D. A., Rowden, A. A., et al. (2018). Earthquakes drive large-scale submarine canyon development and sediment supply to deep-ocean basins. Sci. Adv. 4:eaar3748. doi: $10.1126 /$ sciadv.aar3748

Mulder, T., and Svytski, J. P. M. (1995). Turbidity currents generated at river mouths during exceptional discharges to the world oceans. J. Geol. 103, 285-299.

Mulder, T., Syvitski, J. P. M., Migeon, S., Faugères, J.-C., and Savoye, B. (2003). Marine hyperpycnal flows: initiation, behavior and related deposits. A review. Mar. Pet. Geol. 20, 861-882.

Mulder, T., Zaragosi, S., Garlan, T., Mavel, J., Cremer, M., Sottolichio, A., et al. (2012). Present deep-submarine canyons activity in the Bay of Biscay (NE Atlantic). Mar. Geol. 295, 113-127.

Muthukumar, T., Aravinthan, A., Lakshimi, K., Venkatesan, R., Vedaprakash, L., and Doble, M. (2011). Fouling and stability of polymers and composites in marine environment. Int. Biodeter. Biodegr. 62, 276-284.

Mutti, E., and Normark, W. (1991). "An integrated approach to the study of turbidite systems," in Seismic Facies and Sedimentary Processes of Submarine Fans and Turbidite Systems, eds P. Weimer and M. Link (New York, NY: Springer-Verlag), 75-106.

Näkki, P., Setälä, O., and Lehtiniemi, M. (2017). Bioturbation transports secondary microplastics to deeper layers in soft marine sediments of the northern Baltic Sea. Mar. Pollut. Bull. 119, 255-261. doi: 10.1016/j.marpolbul.2017. 03.065

Nardin, T. R., Hein, F. J., Gorsline, D. S., and Edwards, B. D. (1979). “A review of mass movement processes, sediment and acoustic characteristics, and contrasts in slope and base-of-slope systems versus canyon-fan-basin floor systems," in Geology of Continental Slopes, Vol. 27, eds L. H. Doyle and O. H. Pilkey (SEPM Special Publication), 61-73.

Nelms, S. E., Barnett, J., Brownlow, A., Davison, N. J., Deaville, R., Galloway, T. S., et al. (2019). Microplastics in marine mammals stranded around the British coast: ubiquitous but transitory? Sci. Rep. 9:1075. doi: 10.1038/s41598-01837428-3

Nelson, C. H., Twichell, D. C., Schwab, W. C., Lee, H. J., and Kenyon, N. H. (1992). Upper Pleistocene turbidite sand beds and chaotic silt beds in the channelized, distal, outer-fan lobes of the Mississippi fan. Geology 20, 693-696.

Nisbet, E. G., and Piper, D. J. (1998). Giant submarine landslides. Nature 392, 329-330.

Normark, W. R. (1970). Growth patterns of deep-sea fans. AAPG Bull. 54, 2170-2195.

Normark, W. R. (1978). Fan valleys, channels, and depositional lobes on modern submarine fans: characters for recognition of sandy turbidite environments. AAPG Bull. 62, 912-931.

Normark, W. R., Damuth, J. E., and The Leg 155 Sedimentology Group (1997). "Sedimentary facies and associated depositional elements of the Amazon Fan," in Proceedings of the Ocean Drilling Programme, Scientific Results, Leg 155, eds R. D. Flood, D. J. W. Piper, A. Klaus, and L. C. Peterson (College Station, TX: Ocean Drilling Programme), 611-651.

Obelcz, J., Xu, K., Georgiou, I. Y., Maloney, J., Bentley, S. J., and Miner, M. D. (2017). Sub-decadal submarine landslides are important drivers of deltaic sediment flux: Insights from the Mississippi River Delta Front. Geology 45, 703-706.

Oehmig, R. (1993). Entrainment of planktonic foraminifera: effect of bulk density. Sedimentology 40, 869-877.
Orange, D. L., McAdoo, B. G., Moore, J. C., Tobin, H., Screaton, E., Chezar, H., et al. (1997). Headless submarine canyons and fluid flow on the toe of the Cascadia accretionary complex. Basin Res. 9, 303-312.

Palanques, A., Guillén, J., and Puig, P. (2001). Impact of bottom trawling on water turbidity and muddy sediment of an unfished continental shelf. Limnol. Oceanogr. 46, 1100-1110.

Patters, C. A., and Bratton, S. P. (2016). Urbanization is a major influence on microplastic ingestion by sunfish in the Brazos River Basin, Central Texas, USA. Environ. Pollut. 210, 380-387. doi: 10.1016/j.envpol.2016.01.018

Paull, C. K., Greene, H. G., Ussler, W., and Mitts, P. J. (2002). Pesticides as tracers of sediment transport through Monterey Canyon. Geo Mar. Lett. 22, 121-126. doi: 10.1007/s00367-002-0110-1

Paull, C. K., Mitts, P., Ussler, B., Keaten, R., and Greene, H. G. (2005). Trail of sand in upper Monterey Canyon: offshore California. Geol. Soc. Am. Bull. 117, 1134-1145. doi: 10.1130/B25390.1

Paull, C. K., Talling, P. J., Maier, K. L., Parsons, D., Xu, J., Caress, D. W., et al. (2018). Powerful turbidity currents driven by dense basal layers. Nat. Commun. 9:4114. doi: 10.1038/s41467-018-06254-6

Peakall, J., McCaffrey, W. D., and Kneller, B. C. (2000). A process model for the evolution, morphology and architecture of meandering submarine channels. J. Sediment. Res. 70, 434-448.

Peng, X., Chen, M., Chen, S., Dasgupta, S., Xu, H., Ta, K., et al. (2018). Microplastics contaminate the deepest part of the world's ocean. Geochem. Perspect. Lett. 9, 1-5. doi: 10.7185/geochemlet.1829

Peterson, M. L., Wakeham, S. G., Lee, C., Askea, M. A., and Miquel, J. C. (2005). Novel techniques for collection of sinking particles in the ocean and determining their settling rates. Limnol. Oceanogr. Methods 3, 520-532.

Pham, C. K., Ramirez-Llodra, E., Alt, C. H. S., Amaro, T., Bergmann, M., Canals, M., et al. (2014). Marine litter density and distribution in European seas, from shelves to deep basins. PLoS One 9:e95839. doi: 10.1371/journal.pone. 0095839

Pickering, K. T., Hiscott, R. N., and Hein, F. J. (1989). Deep-Marine Environments-Clastic Sedimentation and Tectonics. Crows Nest: Allen \& Unwin.

Picot, M., Marsset, T., Droz, L., Dennielou, B., Baudin, F., Hermoso, M., et al. (2019). Monsoon control on channel avulsions in the Late Quaternary Congo Fan. Quat. Sci. Rev. 204, 149-171.

Pierdomenico, M., Casalbore, D., and Latino Chiocci, F. (2019). Massive benthic litter funnelled to deep sea by flash-flood generated hyperpycnal flows. Sci. Rep. 9:5330. doi: 10.1038/s41598-019-41816-8

Piper, D. J. W., and Normark, W. R. (1983). Turbidite depositional patterns and flow characteristics, Navy submarine fan, California Borderland. Sedimentology 30, 681-694.

Piper, D. J. W., and Savoye, B. (1993). Processes of late Quaternary turbidity current flow and deposition on the Var Deep-sea fan, North-west Mediterranean Sea. Sedimentology 40, 557-582.

Plastics Europe (2013). Plastics - the Facts an Analysis of European Latest Plastics Production, Demand and Waste Data. Brussels: Plastics Europe, 40.

Pope, E. L., Talling, P. J., Carter, L., Clare, M. A., and Hunt, J. E. (2017). Damaging sediment density flows triggered by tropical cyclones. Earth Planet. Sci. Lett. 458, 161-169.

Prélat, A., Hodgson, D. M., and Flint, S. S. (2009). Evolution, architecture and hierarchy of distributary deep-water deposits: a high-resolution outcrop investigation from the Permian Karoo Basin, South Africa. Sedimentology 56, 241-270.

Ptacnik, R., Diehl, S., and Berger, S. (2003). Performance of sinking and nonsinking phytoplankton taxa in a gradient of mixing depth. Limnol. Oceanogr. 48, 1903-1912.

Rabouille, C., Olu, K., Baudin, F., Khripounoff, A., Dennielou, B., Arnaud-Haond, S., et al. (2017). The Congolobe project, a multidisciplinary study of Congo deep-sea fan lobe complex: overview of methods, strategies, observations and sampling. Deep Sea Res. Part 2 Top. Stud. Oceanogr. 142, 7-24.

Rebesco, M., Hernández-Molina, F. J., Van Rooij, D., and Wåhlin, A. (2014). Contourites and associated sediments controlled by deep-water circulation processes: state-of-the-art and future considerations. Mar. Geol. 352, 111-154.

Rex, M. A., Etter, R. J., Morris, J. S., Crouse, J., McClain, C. R., Johnson, N. A., et al. (2006). Global bathymetric patterns of standing stock diversity and body size in the deep-sea benthos. Mar. Ecol. Prog. Ser. 317, 1-8. 
Ridderinkhof, H., Van der Werf, P. M., Ullgren, J. E., Van Aken, H. M., Van Leeuwen, P. J., and De Ruijter, W. P. M. (2010). Seasonal and interannual variability in the Mozambique Channel from moored current observations. J. Geophys. Res. 115:C06010

Rochman, C. M. (2015). "The complex mixture, fate and toxicity of chemicals associated with plastic debris in the marine environment," in Marine Anthropogenic Litter, eds M. Bergmann, L. Gutow, and M. Klages (Berlin: Springer), 117-140. doi: 10.1007/978-3-319-16510-3

Romans, B. W., Castelltort, S., Covault, J. A., Fildani, A., and Walsh, J. P. (2016). Environmental signal propagation in sedimentary systems across timescales. Earth Sci. Rev. 153, 7-29.

Rusnak, G. A., and Nesteroff, W. D. (1963). Modern turbidites: terrigenous abyssal plain versus bioclastic basin. AAPG Bull. 47, 368-368.

Ryan, P. G., Moore, C. J., vanFraneker, J. A., and Moloney, C. L. (2009). Monitoring the abundance of plastic debris in the marine environment. Philos. Trans. R. Soc. B 364, 1999-2012.

Saller, A., Werner, K., Sugiaman, F., Cebastiant, A., May, R., Glenn, D., et al. (2008). Characteristics of Pleistocene deep-water fan lobes and their application to an upper Miocene reservoir model, offshore East Kalimantan, Indonesia. AAPG Bull. 92, 919-949.

Sanchez-Vidal, A., Thompson, R. C., Canals, M., and de Haan, W. P. (2018). The imprint of microfibres in southern European deep seas. PLoS One 13:e0207033. doi: 10.1371/journal.pone.0207033

Schlining, K., von Thun, S., Kuhnz, L., Schlining, B., Lundsten, L., Stout, N. J., et al. (2013). Debris in the deep: using a 22-year video annotation database to survey marine litter in Monterey Canyon, central California, USA. Deep Sea Res. Part 1 Oceanogr. Res. Pap. 79, 96-105. doi: 10.1016/j.dsr.2013.05.006

Setälä, O., Fleming-Lehtinen, V., and Lehtiniemi, M. (2014). Ingestion and transfer of microplastics in the planktonic food web. Environ. Pollut. 185, 77-78. doi: 10.1016/j.envpol.2013.10.013

Shah, A. A., Hasan, F., Hameed, A., and Ahmed, S. (2008). Biological degradation of plastics: a comprehensive review. Biotechnol. Adv. 26, 246-265. doi: 10.1016/ j.biotechadv.2007.12.005

Shapiro, G. I., Huthnance, J. M., and Ivanov, V. V. (2003). Dense water cascading off the continental shelf. J. Geophys. Res. 108:3390. doi: 10.1146/annurevmarine-010213-135037

Sharma, S., and Chatterjee, S. (2017). Microplastic pollution, a threat to marine ecosystem and human health: a short review. Environ. Sci. Pollut. Res. 24, 21530-21547. doi: 10.1007/s11356-017-9910-8

Shepard, F. P. (1955). Delta-front valleys bordering the Mississippi distributaries. Geol. Soc. Am. Bull. 66, 1489-1498.

Shepard, F. P. (1975). Progress of internal waves along submarine canyons. Mar. Geol. 19, 131-138.

Silva, T. A., Girardclos, S., Stutenbecker, L., Bakker, M., Costa, A., Schlunegger, F., et al. (2018). The sediment budget and dynamics of a delta-canyon-lobe system over the anthropocene timescale: the Rhone river delta, Lake Geneva (Switzerland/France). Sedimentology 66, 838-858.

Smith, D. P., Kvitek, R., Iampietro, P. J., and Wong, K. (2007). Twenty-nine months of geomorphic change in upper Monterey Canyon (2002-2005). Mar. Geol. 236, 79-94.

Smith, M. E., Werner, S. H., Buscombe, D., Finnegan, N. J., Sumner, E. J., and Mueller, E. R. (2018). Seeking the shore: Evidence for active submarine canyon head incision due to coarse sediment supply and focusing of wave energy. Geophys. Res. Lett. 45, 12403-12413.

Sømme, T. O., Helland-Hansen, W., Martinsen, O. J., and Thurmond, J. B. (2009). Relationships between morphological and sedimentological parameters in source-to-sink systems: a basis for predicting semi-quantitative characteristics in subsurface systems. Basin Res. 21, 361-387.

Southern, S. J., Kane, I. A., Warchoł, M. J., Porten, K. W., and McCaffrey, W. D. (2017). Hybrid event beds dominated by transitional-flow facies: character, distribution and significance in the Maastrichtian Springar Formation, north-west Vøring Basin, Norwegian Sea. Sedimentology 64, $747-776$.

Soutter, E., Kane, I. A., and Huuse, M. (2018). Giant submarine landslide triggered by Paleocene mantle plume activity in the North Atlantic. Geology 46, 511-514.

Sparkes, R. B., Lin, I. T., Hovius, N., Galy, A., Liu, J. T., Xu, X., et al. (2015). Redistribution of multi-phase particulate organic carbon in a marine shelf and canyon system during an exceptional river flood: Effects of Typhoon Morakot on the Gaoping River-Canyon system. Mar. Geol. 363, 191-201.

Spychala, Y. T., Hodgson, D. M., Prélat, A., Kane, I. A., Flint, S. S., and Mountney, N. P. (2017). Frontal and lateral submarine lobe fringes: comparing sedimentary facies, architecture and flow processes. J. Sediment. Res. 87, 75-96.

Stanley, D. J. (1982). Welded slump-graded sand couplets: evidence for slide generated turbidity currents. Geo Mar. Lett. 2, 149-155.

Stevenson, C. J., Feldens, P., Georgiopoulou, A., Schönke, M., Krastel, S., Piper, D. J., et al. (2018). Reconstructing the sediment concentration of a giant submarine gravity flow. Nat. Commun. 9:2616. doi: 10.1038/s41467-01805042-6

Stevenson, C. J., Jackson, C. A. L., Hodgson, D. M., Hubbard, S. M., and Eggenhuisen, J. T. (2015). Deep-water sediment bypass. J. Sediment. Res. 85, 1058-1081.

Stolte, A., Forster, S., Gerdts, G., and Schubert, H. (2015). Microplastic concentrations in beach sediments along the German Baltic coast. Mar. Pollut. Bull. 99, 216-229. doi: 10.1016/j.marpolbul.2015.07.022

Stow, D. A. (1991). Distinguishing between Fine-Grained Turbidites and Contourites on the Nova Scotian Deep-Water Margin. Deep-Water Turbidite Syst. 149-165.

Stow, D. A. V., and Faugères, J. C. (2008). "Contourite facies and the facies model," in Contourites, Developments in Sedimentology, Vol. 60, eds M. Rebesco and A. Camerlenghi (Amsterdam: Elsevier), 223-256.

Stow, D. A. V., and Lovell, J. P. B. (1979). Contourites: their recognition in modern and ancient sediments. Earth Sci. Rev. 14, 251-291.

Symons, W. O., Sumner, E. J., Cartigny, M. J. B., and Clare, M. A. (2016). Largescale sediment waves and scours on the modern seafloor and their implications for the prevalence of supercritical flow. Mar. Geol. 371, 130-148. doi: 10.1016/j. margeo.2015.11.009

Talling, P. J., Clare, M. L., Urlaub, M., Pope, E., Hunt, J. E., and Watt, S. F. (2014). Large submarine landslides on continental slopes: geohazards, methane release, and climate change. Oceanography 27, 32-45.

Talling, P. J., Paull, C. K., and Piper, D. J. W. (2013). How are subaqueous sediment density flows triggered, what is their internal structure and how does it evolve? Direct observations from monitoring of active flows. Earth Sci. Rev. 125, 244-287.

Talling, P. J., Sumner, E. J., Masson, D. G., and Malgesini, G. (2012a). Subaqueous sediment density flows: depositional processes and deposit types. Sedimentology 59, 1937-2003. doi: 10.1111/j.1365-3091.2012.01353.x

Talling, P. J., Malgesini, G., and Felletti, F. (2012b). Can liquefied submarine debris flows deposit clean sandstone over large areas? Field evidence from the Marnoso-Arenacea Formation, Italian Apennines. Sedimentology 59, 19372003.

Taylor, M. L., Gwinnett, C., Robinson, L. F., and Woodall, L. C. (2016). Plastic microfibre ingestion by deep-sea organisms. Sci. Rep. 6:33997. doi: 10.1038/ srep33997

ter Halle, A., Ladirat, L., Gendre, X., Goudouneche, D., Pusineri, C., Routaboul, C., et al. (2016). Understanding the fragmentation pattern of marine plastic debris. Environ. Sci. Technol. 50, 5668-5675. doi: 10.1021/acs.est.6b00594

Teuten, E. L., Saquing, J. M., Knappe, D. R., Barlaz, M. A., Jonsson, S., Björn, A., et al. (2009). 'Transport and release of chemicals from plastics to the environment and to wildlife'. Philos. Trans. R. Soc. B Biol. Sci. 364, 2027-2045. doi: $10.1098 /$ rstb.2008.0284

Thompson, R. C., Olsen, Y., Mitchell, R. P., Davis, A., Rowland, S. J., John, A. W. G., et al. (2004). Lost at sea: Where is all the plastic? Science 304:838.

Tubau, X., Canals, M., Lastras, G., Rayo, X., Rivera, J., and Amblas, D. (2015). Marine litter on the floor of deep submarine canyons of the northwestern Mediterranean sea: the role of hydrodynamic processes. Prog. Ocean 134, 379-403.

Twichell, D. C., Schwab, W. C., Nelson, C. H., Kenyon, N. H., and Lee, H. J. (1992). Characteristics of a sandy depositional lobe on the outer Mississippi fan from DeaMARC IA sidescan sonar images. Geology 20, 689-692.

Underwood, A., Chapman, M., and Browne, M. A. (2017). Some problems and practicalities in design and interpretation of samples of microplastic waste. Anal. Methods 9, 1332-1345.

United Nations Environment Programme [UNEP] (2016). Marine Plastic Debris and Microplastics - Global Lessons and Research to Inspire Action and Guide Policy Change. Nairobi: United Nations Environment Programme. 
United States Environmental Protection Agency [USEPA] (1992). Plastic Pellets in the Aquatic Environment: Sources and Recommendations. EPA Oceans and Coastal Protection Division Report 842-B-92-010. Washington, DC: EPA.

Urlaub, M., Talling, P. J., and Masson, D. G. (2013). Timing and frequency of large submarine landslides: implications for understanding triggers and future geohazard. Quat. Sci. Rev. 72, 63-82.

Van Cauwenberghe, L., Devriese, L., Galgani, F., Robbens, J., and Janssen, C. R. (2015). Microplastics in sediments: a review of techniques, occurrence and effects. Mar. Environ. Res. 111, 5-17. doi: 10.1016/j.marenvres.2015.06.007

Van Cauwenberghe, L., and Janssen, C. R. (2014). Microplastics in bivalves cultured for human consumption. Environ. Pollut. 193, 65-70. doi: 10.1016/j.envpol. 2014.06.010

Van Cauwenberghe, L., Vanreusel, A., Mees, J., and Janssen, C. R. (2013). Microplastic pollution in deep-sea sediments. Environ. Pollut. 182, 495-499. doi: 10.1016/j.envpol.2013.08.013

Vendettuoli, D., Clare, M., Hughes Clarke, J., Talling, P., Cartigny, M., Hubbard, S., et al. (2019). Daily bathymetric surveys document how stratigraphy is built and its extreme incompleteness in submarine channels. Earth Planet. Sci. Lett. $515,231-247$.

Vetter, E. W., and Dayton, P. K. (1998). Macrofaunal communities within and adjacent to a detritus-rich submarine canyon system. Deep Sea Res. Part 2 Top. Stud. Oceanogr. 45, 25-54.

Vianello, A., Boldrin, A., Guerriero, P., Moschino, V., Rella, R., Sturaro, A., et al. (2013). Microplastic particles in sediments of Lagoon of Venice, Italy: first observations on occurrence, spatial patterns and identification'. Estuar. Coast. Shelf Sci. 130, 54-61.

von Moos, N., Burkhardt-Holm, P., and Koehler, A. (2012). Uptake and effects of microplastics on cells and tissues of the blue mussel Mytilus edulis L. after experimental exposure. Environ. Sci. Technol. 46, 11327-11335. doi: 10.1021/ es $302332 \mathrm{w}$

Walker, R. G. (1978). Deep-water sandstone facies and ancient submarine fans: models for exploration and stratigraphic traps. AAPG Bull. 62, 932-966.

Ward, J. E., and Shumway, S. E. (2004). Separating the grain from the chaff: particle selection in suspension- and deposit-feeding bivalves. J. Exp. Mar. Biol. Ecol. $300,83-130$

Waters, C. N., Zalasiewicz, J., Summerhayes, C., Barnosky, A. D., Poirier, C., Gałuszka, A., et al. (2016). The Anthropocene is functionally and stratigraphically distinct from the holocene. Science 351:aad2622. doi: 10.1126/ science.aad 2622

Weaver, P. P. E., and Rothwell, R. G. (1987). "Sedimentation on the madeira abyssal plain over the last 300000 years," in Geological Society of Abyssal Plains, eds P. P. E. Weaver, and J. Thomson (London: Special Publications), 31, 71-86.

Wetzel, A. (1991). Ecologic interpretation of deep-sea trace fossil communities. Palaeogeogr. Palaeoclimatol. Palaeoecol. 85, 47-69.
Willis, K. A., Eriksen, R., Wilcox, C., and Hardesty, B. D. (2017). Microplastic Distribution at Different Sediment Depths in an Urban Estuary. Front. Mar. Sci. 4:419. doi: 10.3389/fmars.2017.00419

Woodall, L. C., Sanchez-Vidal, A., Canals, M., Paterson, G. L. J., Coppock, R., Sleight, V., et al. (2014). The deep sea is a major sink for microplastic debris. R. Soc. Open Sci. 1:140317. doi: 10.1098/rsos.140317

Wright, S. L., Thompson, R. C., and Galloway, T. S. (2013). The physical impacts of microplastics on marine organisms: a review. Environ. Pollut. 178, 483-492. doi: 10.1016/j.envpol.2013.02.031

Xu, J. P., Noble, M., Eittreim, S. L., Rosenfeld, L. K., Schwing, F. B., and Pilskaln, C. H. (2002). Distribution and transport of suspended particulate matter in Monterey Canyon, California. Mar. Geol. 181, 215-234.

Yamada, Y., Fukuda, H., Inoue, K., Kogure, K., and Nagata, T. (2013). Effects of attached bacteria on organic aggregate settling velocity in seawater. Aquat. Microb. Ecol. 70, 261-272. doi: 10.3354/ame01658

Young, D. K., Walter, W. H., Richardson, M. D., and Lohanwick, A. W. (1985). Photographs of deep-sea lebensspuren: a comparison of sedimentary processes in the Venezuela Basin, Caribbean Sea. Mar. Geol. 68, 269-301.

Zalasiewicz, J., Waters, C. N., Ivar do Sul, J. A., Corcoran, P. L., Barnosky, A. D., Cearreta, A., et al. (2016). The geological cycle of plastics and their use as a stratigraphic indicator of the Anthropocene. Anthropocene 13, 4-17. doi: 10.1016/j.ancene.2016.01.002

Zavala, C., Arcuri, M., and Blanco Valiente, L. (2012). The importance of plant remains as diagnostic criteria for the recognition of ancient hyperpycnites. Rev. Paléobiol. 11, 457-469.

Zhao, Z., Alford, M. H., Lien, R.-C., Gregg, M. C., and Carter, G. S. (2012). Internal tides and mixing in a submarine canyon with time-varying stratification. J. Phys. Oceanogr. 42, 2121-2142.

Zitko, V., and Hanlon, M. (1991). Another source of pollution by plastics: skin cleaners with plastic scrubbers. Mar. Pollut. Bull. 22, 41-42.

Conflict of Interest Statement: The authors declare that the research was conducted in the absence of any commercial or financial relationships that could be construed as a potential conflict of interest.

The reviewer AG declared a past co-authorship with one of the authors MC to the handling Editor.

Copyright $\odot 2019$ Kane and Clare. This is an open-access article distributed under the terms of the Creative Commons Attribution License (CC BY). The use, distribution or reproduction in other forums is permitted, provided the original author(s) and the copyright owner(s) are credited and that the original publication in this journal is cited, in accordance with accepted academic practice. No use, distribution or reproduction is permitted which does not comply with these terms. 